\title{
Major dust events in Europe during marine isotope stage 5 (130-74 ka): a climatic interpretation of the "markers"
}

\author{
D.-D. Rousseau ${ }^{1,2}$, M. Ghil ${ }^{1,3,4}$, G. Kukla ${ }^{2}$, A. Sima ${ }^{1}$, P. Antoine ${ }^{5}$, M. Fuchs ${ }^{6}$, C. Hatté ${ }^{7}$, F. Lagroix ${ }^{8}$, M. Debret ${ }^{1, *}$, and \\ O. Moine $\mathbf{5}^{5}$ \\ ${ }^{1}$ Ecole Normale Supérieure, Laboratoire de Météorologie Dynamique, UMR8539 CNRS, \& CERES-ERTI, 24 rue Lhomond, \\ 75231 Paris cedex 05, France \\ ${ }^{2}$ Lamont-Doherty Earth Observatory of Columbia University, Palisades, NY 10964, USA \\ ${ }^{3}$ Department of Atmospheric and Oceanic Sciences, University of California, Los Angeles, CA 90095-1565, USA \\ ${ }^{4}$ Institute of Geophysics and Planetary Physics, University of California, Los Angeles, CA 90095-1567, USA \\ ${ }^{5}$ Laboratoire de Géographie Physique, UMR8591 CNRS, 1 place Aristide Briand, 92195 Meudon, France \\ ${ }^{6}$ Department of Geography, Justus-Liebig-University Giessen, 35390 Giessen, Germany \\ ${ }^{7}$ Laboratoire des Sciences du Climat et de l'Environement, UMR8212 CEA-CNRS-UVSQ, Domaine du CNRS, \\ 91198 Gif-sur-Yvette, France \\ ${ }^{8}$ Institut de Physique du Globe de Paris, Sorbonne Paris Cité, University Paris Diderot, UMR7154 CNRS, 75005 Paris, France \\ *now at: Morphodynamique Continentale et Côtière, UMR6143 CNRS, University of Rouen, \\ 76821 Mont-Saint-Aignan Cedex, France
}

Correspondence to: D.-D. Rousseau (denis.rousseau@1md.ens.fr)

Received: 6 April 2013 - Published in Clim. Past Discuss.: 2 May 2013

Revised: 29 July 2013 - Accepted: 8 August 2013 - Published: 26 September 2013

\begin{abstract}
At present, major dust storms are occurring at midlatitudes in the Middle East and Asia, as well as at low latitudes in Northern Africa and in Australia. Western Europe, though, does not experience such dramatic climate events, except for some African dust reaching it from the Sahara. This modern situation is of particular interest, in the context of future climate projections, since the present interglacial is usually interpreted, in this context, as an analog of the warm Eemian interval. European terrestrial records show, however, major dust events during the penultimate interglacial and early glacial. These events are easily observed in loess records by their whitish-color deposits, which lie above and below dark chernozem paleosols in Central European records of Marine Isotope Stage (MIS) 5 age.

We describe here the base of the Dolni Vestonice (DV) loess sequence, Czech Republic, as the reference of such records. The dust is deposited during intervals that are characterized by poor vegetation - manifested by high $\delta^{13} \mathrm{C}$ values and low magnetic susceptibility - while the fine sand and clay in the deposits shows grain sizes that are clearly different from the overlying pleniglacial loess deposits. Some of
\end{abstract}

these dust events have been previously described as "Markers" or Marker Silts (MS) by one of us (G. Kukla), and are dated at about 111-109 ka and 93-92 ka, with a third and last one slightly visible at about $75-73 \mathrm{ka}$. Other events correspond to the loess material of Kukla's cycles, and are described as eolian silts (ES); they are observed in the same DV sequence and are dated at about 106-105 ka, 88-86 ka, and $78.5-77 \mathrm{ka}$. These dates are determined by considering the OSL ages with their errors measured on the studied sequence, and the comparison with Greenland ice-core and European speleothem chronologies.

The fine eolian deposits mentioned above, MS as well as ES, correspond to short events that lasted about $2 \mathrm{ka}$; they are synchronous with re-advances of the polar front over the North Atlantic, as observed in marine sediment cores. These deposits also correlate with important changes observed in European vegetation. Some ES and MS events appear to be coeval with significant dust peaks recorded in the Greenland ice cores, while others are not. This decoupling between the European eolian and Greenland dust depositions is of considerable interest, as it differs from the fully glacial situation, in 
which the Eurasian loess sedimentation mimics the Greenland dust record. Previous field observations supported an interpretation of MS events as caused by continental dust storms. We show here, by a comparison with speleothems of the same age found in the northern Alps, that different atmospheric-circulation modes seem to be responsible for the two categories of dust events, MS vs. ES.

\section{Introduction}

Investigations of past dust deposits referred so far to glacial periods, during which fine grained material was supposed to be mobilized and transported by a modified atmospheric circulation constrained by the occurrence of continental ice sheets and sea level lowering. The modern-era situation, though, does not seem to have an obvious analog in the past, considering that Greenland ice cores show a difference in grain size between the dust deposited during glacial intervals - such as marine isotope stages (MIS) 4, 3 and 2 - and interglacial intervals sensu lato, such as MIS 5 (Ruth et al., 2003). Evidence from marine cores shows that the contribution of the present African (Stuut et al., 2005), Asian (Tada et al., 1999), and Australian (Hesse and McTainsh, 2003) deserts was important in the past as well; therefore, physical parameter values required for present dust emission in these areas should still be of use. Transport and deposition rates, however, must have evidently changed because of the different environmental conditions.

In mid-latitudes, paleo-dust material originated mostly from dry riverbeds and emerged areas on the continental shelf, i.e. from regions that do not yield nowadays any dust. These regions were nevertheless particularly active and favored the deposition of mid-latitude loess sequences in the Northern Hemisphere.

Investigating atmospheric dustiness during interglacial intervals appears therefore even more challenging because of limitations in the resolution and completeness of ice core records, especially in the Northern Hemisphere. GRIP members (1993) described brief dust events in the Greenland GRIP ice core at 131 and $115 \mathrm{kyrBP}$, which they named events 2 and 1, respectively, and interpreted them as being of very short duration ( 750 and $70 \mathrm{yr}$ ). Chappellaz et al. (1997), however, used $\mathrm{CH}_{4}$ analyses to challenge some of these claims, and showed that these dust events corresponded to older ice layers injected into the record.

In this paper, we describe several dust event records observed during MIS 5 in terrestrial deposits, and provide an interpretation thereof from a climate dynamics point of view. The next section contains the description of the loess sequences, and the following one their climatic interpretation. A short conclusion section rounds off the paper.

\section{Paleodust records of the last climate cycle}

\subsection{Glacial Interval}

\subsubsection{The Greenland ice cores}

Several ice cores drilled at the summit of the Greenland ice sheet show a highly variable climate during the last climatic cycle, with abrupt warmings followed by a two-step cooling towards stadial conditions. The location of these cores is shown in Fig. 1.

Both the GRIP and GISP2 records present similar features, such as the parallelism between the distinct $\delta^{18} \mathrm{O}$ curves since about $110 \mathrm{ka}$ (Dansgaard et al., 1993). The good correlation with the NorthGRIP record (Andersen et al., 2004) increases further the reliability of these earlier records. Rapid climate variations are also recorded in high-resolution marine cores from the North Atlantic (Bond and Lotti, 1995). So-called Dansgaard-Oeschger (D/O) events (Dansgaard and Oeschger, 1989; Dansgaard et al., 1993) had been recognized in several older Greenland ice cores - see Camp Century and Dye 3 curves (Dansgaard et al., 1982) - but were not widely accepted, especially when compared with lower resolution marine cores (Dansggard et al., 1985).

The dust record in these ice cores also shows variations that follow roughly the D/O pattern, as the stadial intervals always reveal the occurrence of high dust content in the atmosphere, contrary to low dust concentrations during the interstadials (Hammer et al., 1985; Dansgaard et al., 1993) (Fig. 1). Some of the dust-record oscillations were linked with the iceberg-discharge dynamics corresponding to the Heinrich events (Heinrich, 1988; Bond et al., 1992), but are not evidently marked in the isotopic ice-core records.

\subsubsection{Loess sequences}

Loess is mostly an eolian sediment, which generally presents material of local, as well as more regional or dispersed origin (Kukla, 1977; Pécsi, 1990). It corresponds to particular environmental conditions, which made the fine material available - mainly from sandurs or dried braided rivers, moraines, or even emerged landscapes after the lowering of the sea level - and transported this material by strong winds. Considering the loess distribution, the thickness of the sequences, and their eolian origin, loess series are a particularly good continental record of past climates.

During the past decade, new techniques and study protocols have facilitated the use of loess sequences as a sensitive tool to understand past climate dynamics. These techniques include geophysical ones, such as magnetic susceptibility (Kukla et al., 1988; Heller et al., 1991), geochemical ones, such as the analyses of stable isotopes (Gu et al., 1991; Hatté et al., 1998, 2013; Wang et al., 2000), of grain-size (Muhs and Bettis III, 2000; Antoine et al., 2001, 2009a, b, 2013; Rousseau et al., 2007a; Sun et al., 2012; Vandenberghe, 

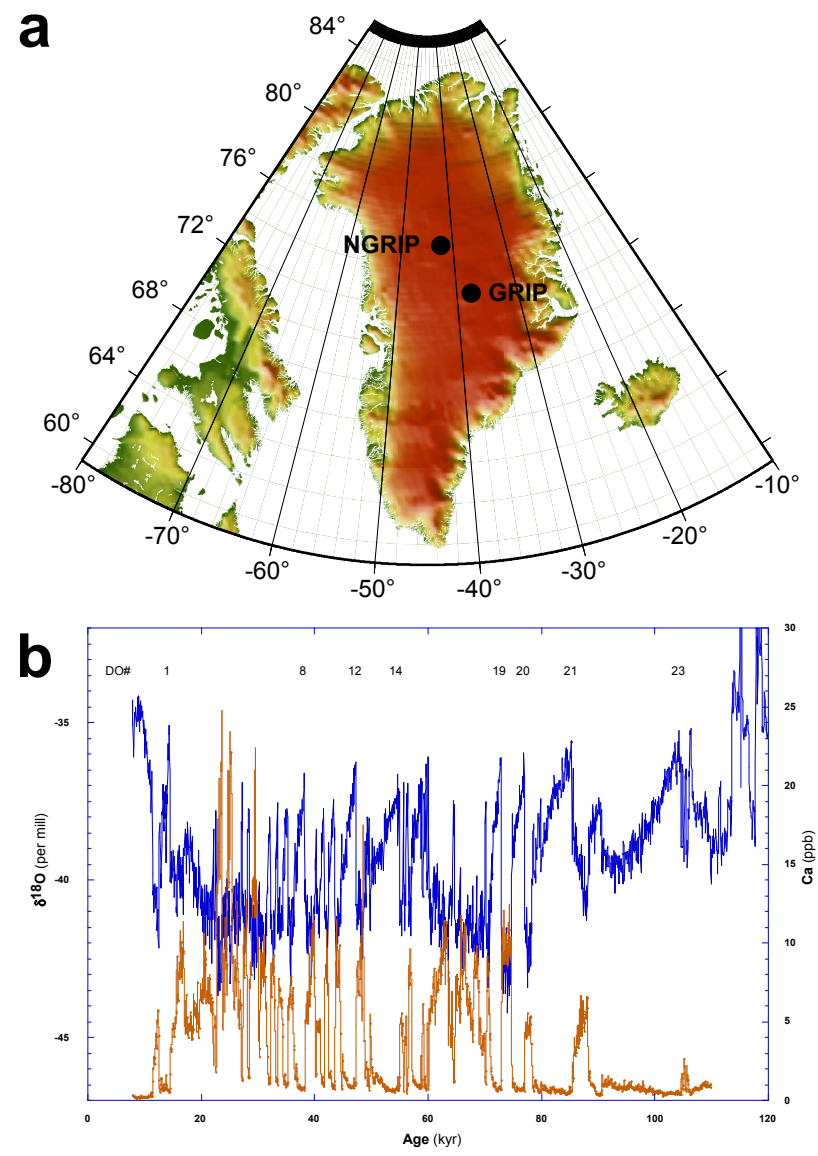

Fig. 1. Greenland ice cores discussed in the text. (a) Location of the GRIP and NGRIP Greenland ice cores. (b) Variation of the $\delta^{18} \mathrm{O}$ (blue curve) and of the dust concentration (red curve) during the last climate cycle in the GRIP ice core (Johnsen et al., 2001) showing the record of the abrupt warming named Dansgaard-Oeschger events associated with abrupt decreases of the dust concentration.

2013), as well as biological indices (Rousseau and Puisségur, 1990; Rousseau et al., 1990; Lu et al., 1991; Rousseau, 1991; Rousseau and Kukla, 1994; Wu et al., 1995; Rousseau and $\mathrm{Wu}, 1997)$. Detailed stratigraphic investigations remain, however, a fundamental tool that is still as important as the more recent and sophisticated approaches.

Chinese loess sequences have been intensively studied by now for their climatic properties (Heller and Liu, 1982; Liu, 1985; Kukla, 1987; Ding et al., 1992; Guo et al., 1996). These sequences show the alternation of paleosol and loess units down to the Quaternary boundary at $2.6 \mathrm{Myr}$, and have recently been expanded to the Tertiary, down to $22 \mathrm{Myr}$ (Guo et al., 2002). The most widespread approaches in their investigation are the study of grain size variations and the analysis of the low magnetic susceptibility hypothesized by Kukla et al. (1988) as a record of the dust input. While Kukla's interpretation of dust deposition was criticized for the soil intervals, because of the partly biological origin of the magnetic grains (Heller et al., 1991), the variation in grain size was used to infer climatic effects linked to the Southeast Asian paleo-monsoon, as well as to North Atlantic variations (Porter and An, 1995).

Focusing on the last climate cycle, several superimposed soils have been described within the $\mathrm{S} 1$ soil complex, which is equivalent to marine MIS 5; some records, located in the northwestern part of the loess plateau, do exhibit the occurrence of loess or eolian layers (An et al., 1991) named S1-2 and S1-4 (Ding et al., 1999). Except for these rare locations, the general stratigraphy of the Chinese loess plateau does not indicate, however, any major dust input during MIS 5. Forster and Heller (1994), Ding et al. (2002) and Shackleton et al. (1995) indicated that, according to magneticsusceptibility studies, the loess stratigraphy in Tajikistan is almost the same as in China. Kukla and colleagues (Smiley et al., 1991) also proposed wider correlations between China, Central Europe and North America by considering the loesspaleosol successions that show a more global pattern in the general loess stratigraphy. In fact, while in China and Tajikistan - and, to some extent, in the Great Plains of North America - the loess sequences corresponds mostly to tabular deposits, building through time a plateau-like structure, the European loess sequences are often deposited on slopes. In that case the sequences are not only a succession of paleosols and loess, like in Asia; instead, they are a succession of soil complexes and loess (Rousseau et al., 2007b).

Numerous stratigraphers have also intensively studied and carefully described European loess sequences; the location of the major sequences is plotted in Fig. 2. Kukla (1961) and Kukla and Lozek (1961) were the first to define a typical stratigraphic sequence for Europe. Their succession is based on cycles and it varies somewhat according to the region considered. Each cycle starts by a thin deposit of hillwash loam, called phase 1. A forest soil of braunerde type (phase 2) follows, covered in turn by a steppe soil of chernozem type (phase 3). An eolian deposit of small thickness, named Marker (phase 4), interrupts this steppe soil, and it is further overlaid by bedded layers of pellet sands, or Lehmbröckelsände (phase 5), and finally a loess layer. Marker units are thin bands of fine-grained silt that separate underlying black humiferous steppe soil from overlying pellet sands; hereafter we will refer to these units as Marker silts (MS). Such cycles can repeat through time, more or less completely.

Investigating the loess member of this cyclic succession, Rousseau et al. (2002) showed that European sequences - located at the winter margin of sea ice extension, at a latitude of about $50^{\circ} \mathrm{N}$, where they are the thickest on average (Fig. 2) - recorded doublets that correspond to successive alternations of paleosols and loess or eolian units. This team of researchers has constrained the cyclic successions well by different dating methods (Hatté et al., 1999; Lang et al., 2003) and it has successfully correlated them with climate variations that represent alternations of warm interstadial D/O events and cold stadial intervals, recorded in Greenland ice 
0

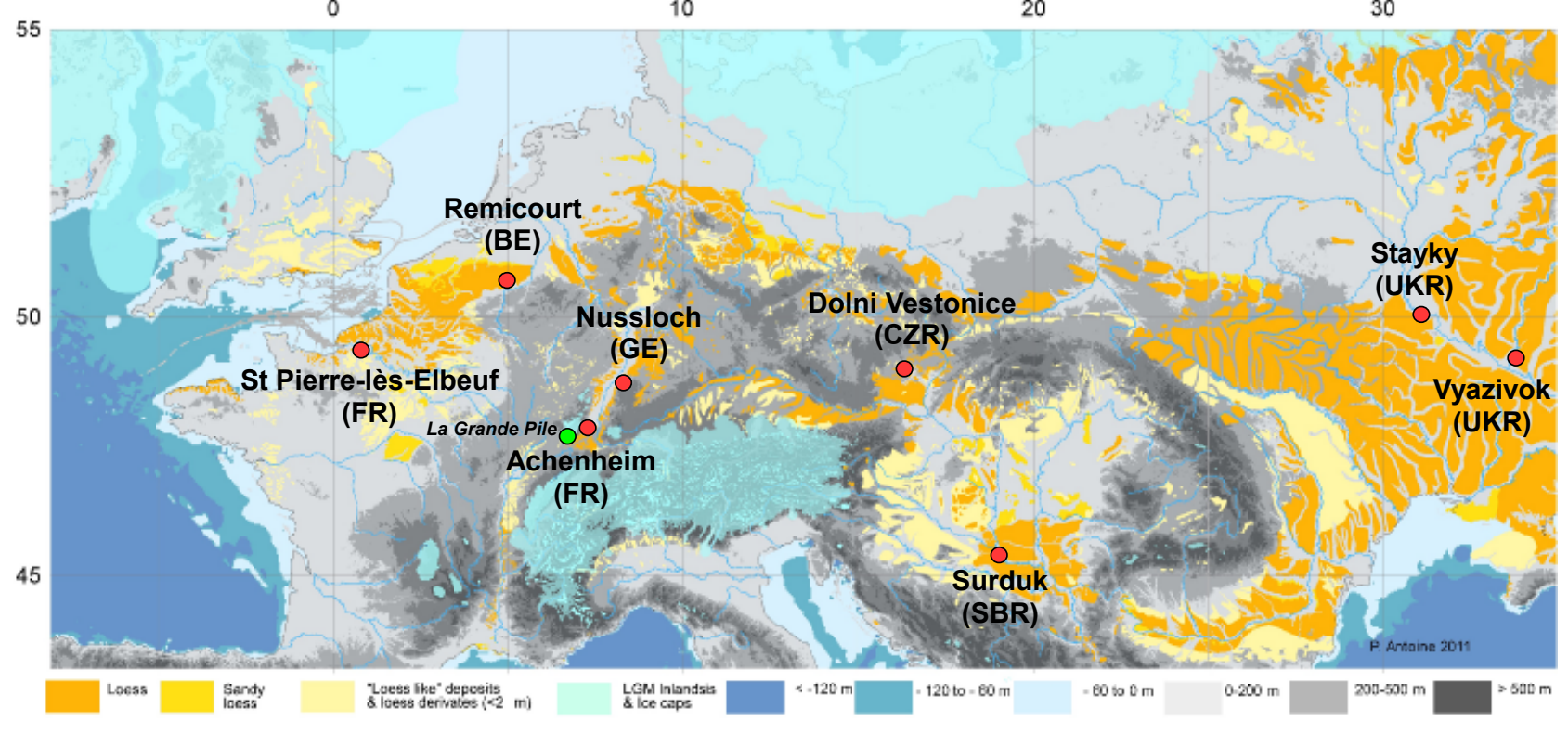

Fig. 2. Location of major European loess sequences. The map, adapted from Antoine et al. (2013), also shows the distribution of the loess deposits (in yellow) by thickness in Europe, as well as the extent of the continental ice sheets (light blue) and the estimated lowering of the sea level (emerged areas in light gray) at the last glacial maximum.

cores and North Atlantic marine-sediment cores (Antoine et al., 2009b).

Rousseau et al. (2011) have provided further evidence of this correlation by showing that the type of paleosol preserved in the continental sequences corresponds directly to the duration of the interstadial preserved in ice and marine cores. This alternating sequence lies over a pedocomplex subsequence showing also a complex succession, which corresponds to previously well-expressed cycles of hillwash loam, paleosol-organic soil, MS, pellet sands, and eolian deposits, as described by Kukla and Lozek (1961). The work performed over the last decade showed, however, that the completeness of the sedimentary cycles corresponds to precise climatic conditions, rather than occurring at random, as originally supposed by Kukla and Lozek (1961).

These observations in terrestrial records could lead one to interpret the variations in the atmospheric dust content recorded in Greenland during MIS 5 as minor climatic phenomena, compared to those of higher magnitude that had been described during MIS 4-2. The isotopic signature of Greenland dust shows similarities with Chinese loess (Biscaye et al., 1997; Svensson et al., 2000), and present dust deposited in Greenland firn exhibits also a Chinese origin, mostly from the northern deserts (Bory et al., 2002). Even though the dust deposition recorded in the Greenland ice sheet during MIS 5 is of lower magnitude than during full glacial times, it would appear that major dust emissions, compared to the present, should have occurred in the deserts of Northern China. This line of reasoning appears to imply favorable environmental conditions for dust emission and transport from these deserts. Considering the tight relationship described between Greenland records and European loess series for the last climate cycle, could such a relationship have also been active during MIS 5? If not, can one or more other mechanisms be proposed?

\subsection{MIS 5 dust record}

\subsubsection{The Greenland ice core GRIP}

The record of major dust events prior to the last glacial time in Greenland ice cores is less well covered in the existing literature. Indeed, from $120 \mathrm{kyr}$ upward, three dust peaks have been reported (GRIP members, 1993; Andersen et al., 2004); they seem to occur just before the boundary between MIS 5 and 4 , at about $74 \mathrm{ka}$ (Fig. 1). These peaks correspond to coolings that are well captured by the $\delta^{18} \mathrm{O}$ curve at $111-$ $98 \mathrm{ka}, 89-85 \mathrm{ka}$, and 79-77 ka, respectively.

In the Southern Hemisphere, the dust content in the Vostok ice core does not show any particular peak (Petit et al., 1990), while both the EDML and EDC ice core records do show dust peaks at about the same time interval as in Greenland (Fischer et al., 2007). These peaks are identified less clearly, however, than in the Greenland $\delta^{18} \mathrm{O}$ and dust records. The difference between the two groups of records indicates that the MIS 5 dust record in Greenland ice cores points to a climate history associated with the Northern Hemisphere, rather than with both hemispheres. Therefore, Northern Hemisphere atmospheric dynamics could have played an important role in the extent to which some, if not all, of these events have been recorded in the above-mentioned continental sequences, especially in the European loess sequences. 


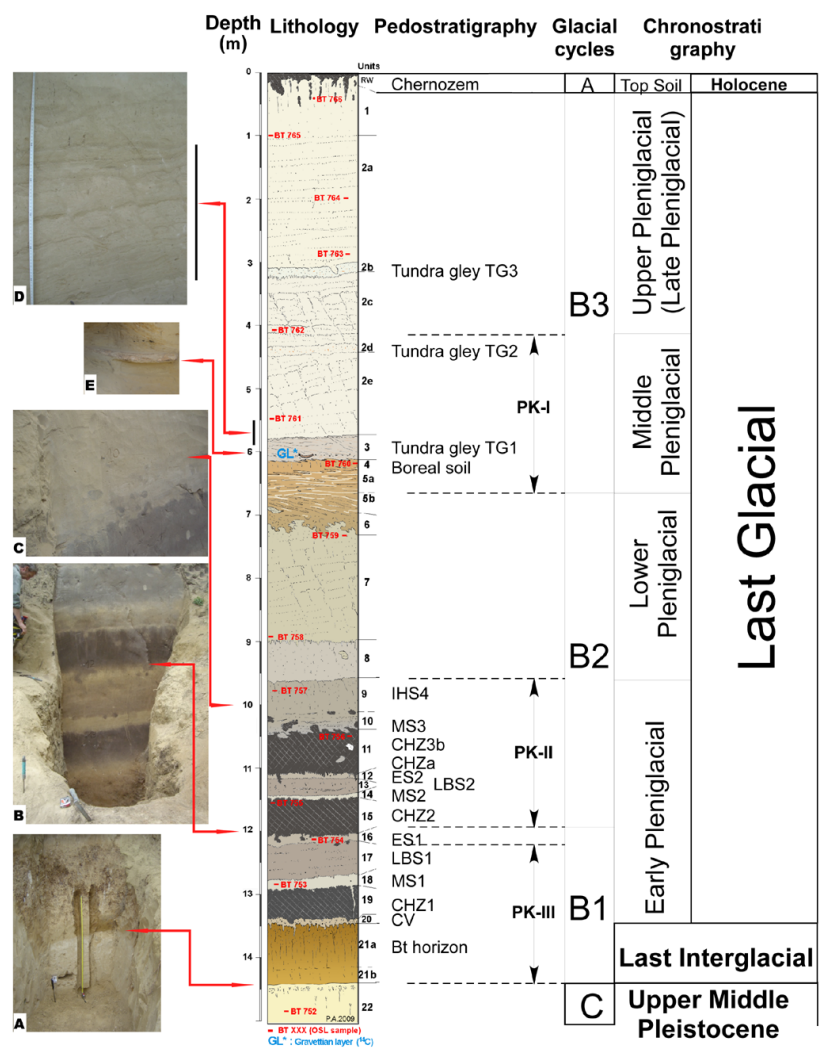

Fig. 3. Stratigraphy of the last climate cycle at Dolni Vestonice (DV), Czech Republic adapted from Antoine et al. (2013). On the right is the chronostratigraphy, in terms of glaciation cycles; in the middle is the pedostratigraphy, with the lithological succession of the soil complexes PK= I, II, and III, according to Kukla (1961); and on the left are given visual snapshots of the sequence: (A) penultimate climate cycle (Saalian loess) and the interglacial Bt paleosol horizon; (B) PKIII and PKII soil complex succession; (C) irregular top of the upper chernozem of the PKII soil complex; (D) Mammoth bone in the Gravetian layer, showing evidence of charcoal; and (E) sandy loess, showing wedges. Lithological log by P. Antoine, in Fuchs et al. (2013), photos DDR. Legend: $\mathrm{Bt}$ - Bt paleosol horizon; CV - colluvium; CHZ - chernozems; LBS -“Lehmbröckelsände" (or Pellet Sands); MS - "marker silt"; ES "eolian silt"; IHS: isohumic soil horizon. The labeling of these units respect the original one from Kukla et al and therefore differs from the one used by Antoine et al. (2013) except for IHS4.

\subsubsection{Central European loess sequences}

Kukla (1961) described three major pedocomplexes - PKIII, PKII and PKI - during the last climatic cycle. In this by now classical interpretation of the Central European loess sequences, the first two were assigned to MIS 5 (Fig. 3). Kukla (1977) noticed the occurrence of three "marker units" in pedocomplexes PKIII and PKII, and interpreted them as corresponding to paleo-dust intervals.

Fuchs et al. (2013) and Antoine et al. (2013) provide further information about these particular dust layers in the Dolni Vestonice (DV) section (Moravia, Czech Republic), which was continuously sampled every $5 \mathrm{~cm}$. First of all, the succession identified in the new section is in total agreement with the previous description of the sequence by B. Klima and G. Kukla in 1968, as published in Demek and Kukla (1969) and by Kukla (1977). A detailed field investigation allowed Fuchs and colleagues (Fuchs et al., 2013) to identify a complex succession of 22 pedosedimentary units for the last climate cycle (Fig. 3).

Based on these 22 units, their sedimentological characteristics and the occurrence of well-developed soil horizons, erosion boundaries and facies changes, four subsequences (I to IV) were distinguished, including the last interglacial paleosol, a Bt horizon (unit 21) to the surface of the upper loess (unit 1), with the first sub-sequence corresponding to the basal humic soil complex (units 20 to 9) including pedocomplexes PKIII and II. The labeling of the units used in this paper corresponds to the original description from Kukla $(1961,1977)$ and not to the new one proposed by Antoine et al. (2013). The choice is made in order to make reference to the original investigations that one interpretation of the origin of the marker silt is tested in this paper. The basal subsequence starts by the forest Bt paleosol (unit 21); a colluvium (CV), a first chernozem (unit 19; CHZ1), interpreted as an isohumic soil horizon (ISH); a marker silt (unit 18, MS 1); pellet sands (Lehmbröckelsände, unit 17), labeled as LBS 1; and an eolian silt (unit 16, ES 2). This succession corresponds to Kukla's (1977) cyclic pattern and to the soil complex PK III. The succession repeats twice thereafter but not completely, inasmuch as the Bt horizon is missing. Chernozem of unit 11 shows a more complex evolution as a light layer divides it into two sub-units, the lowermost being more developed than the upper one, a characteristic that G. Kukla had also described previously, cf. figure Klima and Kukla (1968) in Demek and Kukla (1969) (Fig. 4).

The overlying subsequence II starts with a discontinuity between units 9 and 8 . Unit 8 shows the occurrence of a very distinct sandy component, with increasing fine sand contents from $23 \%$ in unit 8 to $30 \%$ at the top of unit 7 (Fuchs et al., 2013; Antoine et al., 2013).

The multidisciplinary investigation of the DV sequence allows one to describe the variations of several environmental parameters measured along the stratigraphy (Antoine et al., 2013); see Figs. 3 and 5 here. The interglacial paleosol indicates increasing clay content, susceptibility values, total carbonate and negative values towards its top, all of these being features characteristic of the Bt horizon. The chernozems CHZ 2, 3 show high clay content (minimum $35 \%$ ), high susceptibility values (minimum $45 \times 10^{-8} \mathrm{~m}^{3} \mathrm{~kg}^{-1}$ ), increasing carbonate towards the top, and the more negative $\delta^{13} \mathrm{C}$ values, at about $-26 \%$, characteristic of $\mathrm{C} 3$ vegetation. These analytic results (clay and total carbonate content, magnetic susceptibility, $\delta^{13} \mathrm{C}$ ) demonstrate that this unit 11 can be subdivided into two distinct subunits (CHZ 3a and 3b), with the lower soil horizon (CHZ 3a) being more developed (Figs. 3 


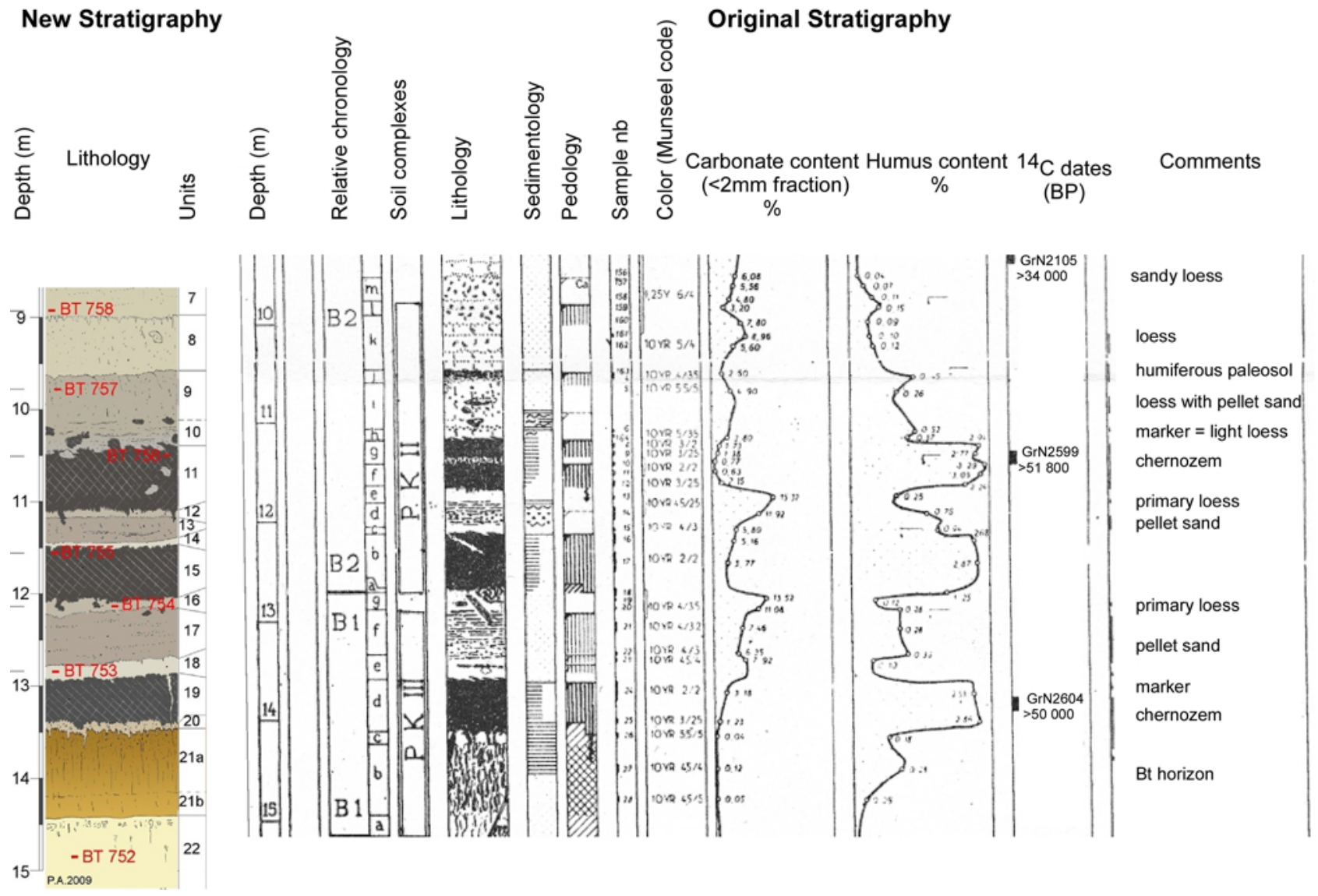

Fig. 4. DV soil complexes. Comparison of the stratigraphy observed in 2009 (Fuchs et al., 2013) and the one described by B. Klima and G. Kukla in 1968, as published in Demek and Kukla (1969).

and 5). Slight differences occur, however, in unit 9, isohumic soil horizon ISH 4, which shows lower values of magnetic susceptibility, carbonate content, less negative $\delta^{13} \mathrm{C}$, and is not marked in the clay content.

The marker silts MS 1,2 and 3 have low clay content, but not as low as the overlying loess units. The magnetic susceptibility is low in MS 1, 2 and 3, but higher than in the chernozems (CHZ). The carbonate content in the marker silts is low (maximum 6-7\%), but slightly higher than in the chernozems, while the $\delta^{13} \mathrm{C}$ indicates less negative values, of about $-25 \%$. The markers show a lower brightness $\left(L^{*}\right.$ between $42 \%$ and $52 \%$ ) and a low iron hydroxide content (FDS 555 between 0.07 and 0.12 ) than the eolian silts. The exact definitions of the two spectrometric parameters - sediment $L^{*}$ (in percentages) and FDS - are given in Debret et al. (2011) and in the caption of Fig. 5.

The ES layers have low clay content, lower even than previously deposited marker silts. The magnetic susceptibility is low, while the total carbonate content is higher than $15 \%$. The $\delta{ }^{13} \mathrm{C}$ indicates more aridity with less negative values that are similar to those measured in the MS layers.

One can argue that clay content is not an especially good index of particle size in studying dust transport. Dust is produced mainly by saltation of lithogenic particles. Thus, when the wind blows sufficiently strongly over a surface not protected by vegetation, relatively coarse particles (e.g., stones, pebbles, and some grains constituting the superficial layer of the soil) are mobilized. Some saltating particles furthermore impact particle aggregates, and their kinetic energy can break the cohesive forces of these aggregates, creating new smaller particles - a process called sandblasting (Gillette and Goodwin, 1974; Gomes et al., 2003; Shao, 2001). Obviously, the available energy depends of the wind speed, but also of the size of the saltating grains. In dust emission, the sandblasting process is primarily controlling the vertical flux of particles. The "dust particles" therein liberated from aggregates, have a diameter generally lower than 20 microns (Nickling, 1998), while no such small particles are present in the soils where they originate. Consequently, while the erosion threshold is not very sensitive to the soil grain size distribution, the vertical dust emission flux is, via the sandblasting. Other important factors for eolian erosion are the soil moisture and roughness height. The effect of soil moisture of increasing the erosion threshold by reinforcing the soil cohesion (Fecan et al., 1999) is rather limited, as the soil surface layer can dry up quickly. On the contrary, the roughness 


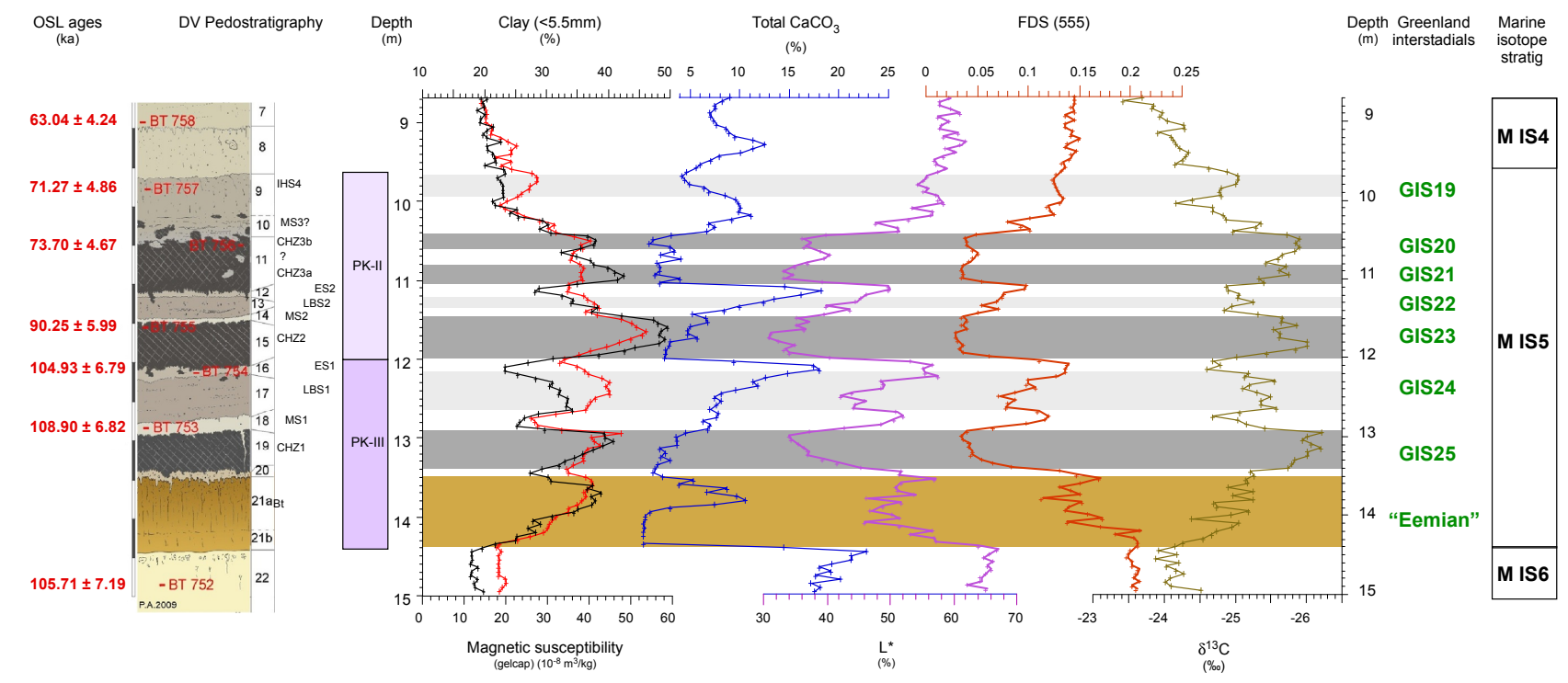

Fig. 5. Continuous, quantitative characterization of the DV soil complexes. On the left are OSL ages (mean \pm error) and the DV pedostratigraphy. In the middle panel, from left to right: clay content $(\%)$, black curve; low-frequency magnetic susceptibility $\left(10^{-8} \mathrm{~m}^{3} \mathrm{~kg}^{-1}\right)$, red curve; total carbonate content $(\%)$, blue curve; two spectrometric parameters - sediment brightness $L^{*}(\%)$, purple curve, and firstderivative spectrum FDS, red curve; and, finally, $\delta^{13} \mathrm{C}$ from organic matter, yellow curve. The FDS plotted here corresponds to the 555-nm band characteristic of iron hydroxides such as goethite (cf. Debret et al., 2011). On the right are the proposed correlations with Greenland interstadials and marine isotope stratigraphy. Eolian events (MS and ES) are clearly individualized, as are chernozems (CHZ - IHS) and "Lehmbröckelsände" (LBS - or pellet sands).

height is key factor acting both on the wind erosion threshold and on the wind friction velocity (Gillette and Chen, 1999). This parameter depends on the local environmental conditions.

However, we deliberately used the clay fraction from the grain size because it corresponds to the maximum size of mineral aerosols that could be taken into account for a modeling purpose. Figure 5 shows differences in the clay content with lower values in the Eolian silts (ES) than in the Marker silts (MS). There are also differences in the low field magnetic susceptibility values. The highest carbonate content in ES compare to MS could be inherited from the chernozem overlying them. Based on this single parameter, this interpretation could be a possible explanation. However, when considering the spectrocolorimetric parameters $L^{*}$ and FDS, this is not the case. This is the reason why, compared to the recently published paper by Antoine et al. (2013), we included these parameters in the present study to differentiate the two types of unit. Debret et al. (2011) provide a very useful review of this powerful method in which they show that $L^{*}$ is a fundamental parameter describing the brightness (total reflectance) of the sediment studied characterizing its carbonate content. FDS on the contrary distinguishes the nature/composition of the sediment and in the band used, the amount of goethite, sensible to moisture. Therefore, differences between MS and ES are much more evident.

Finally the pellet sands (LBS) indicate intermediate values of various parameters between those of the CHZ-ISH and the
MS. The carbonate content, at about $25.5 \%$, is higher than in CHZ-ISH, but lower than in ES or MS. The brightness and iron hydroxide content exhibit values of $L^{*}=50-55 \%$ and FDS 555 between 0.1 and 0.13 , which are intermediate between those that characterize the marker silts and the proper loess unit above pedocomplex PKII; the latter are given by $L^{*}>60 \%$ and FDS $555>0.14$.

The Optical Stimulated Luminescence (OSL) ages derived from different grain size fractions, labeled BT in accordance with the Bayreuth luminescence lab (Fuchs et al., 2013) are the same within measured error limits, and all OSL age estimates are in the proper stratigraphic order (Fuchs et al., 2013). For the OSL dates, we consider the interval given by the measured errors, which show that the stratigraphy of the DV sequence is in good agreement with the $\delta^{18} \mathrm{O}$ stratigraphy from NGRIP (Andersen et al., 2004). The latter $\delta^{18} \mathrm{O}$ stratigraphy is supported in turn by the $\delta^{18} \mathrm{O}$ stratigraphy obtained in the Chinese speleothems from the Hulu and Sanbao caves (Wang et al., 2001, 2008), and in a recently published Northern Alps record (Boch et al., 2011), as shown in Figs. 6 and 7.

OSL sample BT 753 was taken from the homogeneous eolian silt of unit 18 (MS 1), providing an age of 108.9 \pm $6.82 \mathrm{ka}$. Therefore, the sediment was deposited during stage MIS 5d, and hence it represents the first eolian sediment of the Early Glacial. The first chernozem horizon (unit 19, CHZ 1) below this silt layer represents the oldest soil unit of the Weichselian Early Glacial. Assigning numerical ages for the 

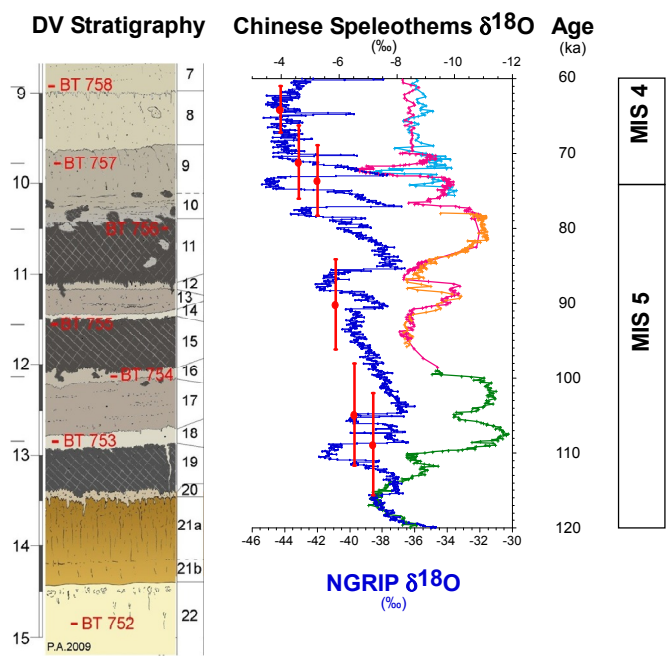

Fig. 6. Dating of DV soil complexes, via correlations with several well-dated records, over the 60-120 ka interval. Left: observed DV stratigraphy; middle: mean position of the DV Optical Stimulated Luminescence (OSL) dates in the Greenland NGRIP $\delta{ }^{18} \mathrm{O}$ stratigraphy (Andersen et al., 2004); and right: comparison between the NGRIP (Andersen et al., 2004) and the Chinese speleothem $\delta^{18} \mathrm{O}$ stratigraphies from the Hulu and Sangbao caves (Wang et al., 2001, 2008).

formation of this humic soil before roughly $110 \mathrm{ka}$ is a first for European Early Glacial soil complexes. According to the $\delta^{18} \mathrm{O}$ curve from North GRIP (Andersen et al., 2004), the humic soil of unit 19 can be assigned to the short Greenland interstadial GIS 25 ( 111-113 ka; cf. Dansgaard et al., 1993). This age assignment also supports the age proposed by Kukla and Koci (1972) for the shift between the forest, represented by chernozem unit 19 , and the steppe, represented by MS1 unit 18; these authors identified the forest-steppe shift with the lower boundary of the geomagnetic Blake event at about $126 \mathrm{ka}$.

The eolian silt layer ES1 corresponds to unit 16 and it yields an OSL date of $104.93 \pm 6.79 \mathrm{ka}$; assuming the completeness of the sequence, these dates correspond to Greenland stadial GS23 (Rousseau et al., 2006b) (Fig. 7). The first Kukla cycle encompasses, therefore, the Last Interglacial, as well as two Greenland stadials and interstadials.

Two other prominent chernozem soil horizons (unit 15, CHZ 2, and unit 11, CHZ 3a and 3b) are observed in the DV stratigraphy. Kukla's cyclic pattern partly occurs twice but in a truncated version (chernozem, marker silt, pellet sands, and eolian silt only), due to the lack of the Bt horizon. These soils correspond to temperate continental intervals, which could roughly be coeval with Greenland insterstadials. Indeed, the OSL sample taken from the upper part of the chernozem of unit 15 is dated to $90.25 \pm 5.99 \mathrm{ka}$ (BT 755) and thus could be correlated with GIS 23, which in turn corresponds to MIS 5c (Andersen et al., 2004).
The OSL sample taken from the top of the following composite chernozem (unit $11-\mathrm{CHZ} 3 \mathrm{a}$ and $3 \mathrm{~b}$ ) is dated to $73.70 \pm 4.67 \mathrm{ka}$ (BT 756), and corresponds to the end of MIS 5a. The upper sub-unit 11, CHZ 3b, can be correlated with GIS 20. Taking into account this dating, the lower horizon of unit 11, CHZ 3a, corresponds most likely to GIS 21 . Finally the succession formed by units 10 and 9 represents the last pedosedimentary cycle of subsequence I, with unit 9 showing a weak humic pedogenesis (IHS 4). Considering the age of BT 757 (71.27 $\pm 4.86 \mathrm{ka})$ obtained for the upper part of unit 9, this part of the section (IHS 4) could represent the last short interstadial, GIS 19, of the Early Glacial, representing the boundary between MIS 5a and MIS 4 (Martinson et al., 1987) (Fig. 7).

\section{Interpretation}

\subsection{Stadial storms as dust Depositors}

Marker silts (MS) are generally finer grained than normal loess, but no significant differences are found in the petrological content or even in the magnetic fabric (Hradilova, 1994; Hradilova and Stastny, 1994). The new results presented in the previous section on the classical DV sequence do not differ from previous descriptions on this point. The source of the dust in the MS layers is, therefore, even more intriguing.

This source could not have been lying close to the location of this soil record, as the surface in the vicinity was covered by black, mostly decalcified and degraded chernozems under grass cover, while the local rivers carried decalcified detritus from the surrounding highlands (Kukla, 1977; Rousseau et al., 1998a). These grey-whitish MS silts must, therewith, be due to long-distance wind transport because of the sharp boundaries between these silts and the adjacent layers. Since the granular composition of the MS layers is much finer than that of loess - with a grain fraction in the range of 0.05 to $0.125 \mathrm{~mm}$, a fraction that can still be moved by local winds - the latter would have caused a much more gradual mixing between the MS and loess layers. This interpretation seems to apply to the eolian silts observed in the DV stratigraphy as well. Furthermore, the chemical, magnetic, and basic mineralogical composition of the MS silts is similar to that of the overlying loess.

The modeling experiments of Sima et al. $(2009,2013)$ on dust emission for stadial conditions in western Europe show that ground surface conditions are most favorable in spring for both the emission and transport of fine-grained material. These favorable conditions arise after harsher winter conditions and before the start of the development of the vegetation, later in the season; the optimal time for dust emission and transport is slightly shifted towards early summer during Heinrich events.

Considering the new OSL dates (Fuchs et al., 2013) and the proposed correlation with Greenland ice-core records, 


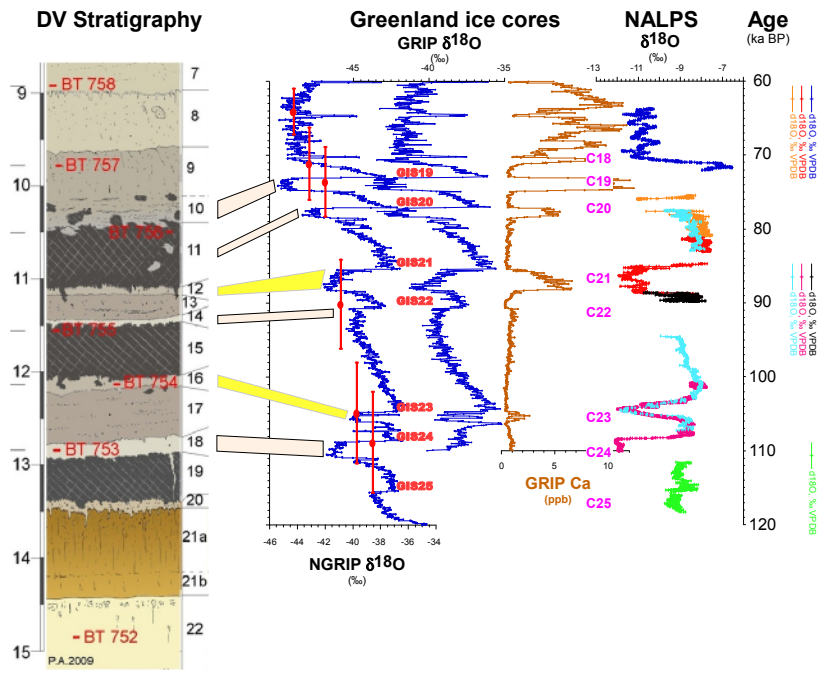

Fig. 7. Correlation between DV soil complexes and several welldated isotopic records. The latter are shown, from left to right, as the three Greenland records of NGRIP $\delta^{18} \mathrm{O}$ (Andersen et al., 2004), GRIP $\delta^{18} \mathrm{O}$ and the GRIP dust record (Johnsen et al., 2001); and the $\delta^{18} \mathrm{O}$ from NALPS speleothems (Boch et al., 2011). Indication of Greenland interstadials (Rousseau et al., 2006b) and of North Atlantic cold events from (McManus et al., 1994).

both MS and ES events in the DV sequence can be linked to several cold events identified in the North Atlantic Ocean (McManus et al., 1994). These cold events have also been associated with drastic vegetation changes in the La Grande Pile pollen sequence (Kukla et al., 1997).

The pollen record in the peat bog at La Grande Pile is located on the southern edge of the Vosges Mountain. This record indicates that, at the time of MS and ES deposition at $\mathrm{DV}$, the vegetation was particularly poor $(80 \%$ of nonarboreal pollen), with steppe conditions over an open landscape (Woillard, 1978). These intervals are named the Ognon stadial II, Melisey II, St. Germain I 5b, Montaigu, Melisey I and Woillard events (Woillard, 1978; Kukla et al., 1997; Rousseau et al., 2006a). Scarce vegetation at European midlatitudes, the contrasted seasonal regime of rivers, and the lowering of the sea level are all favorable conditions for the mobilization of fine material.

Marine records provide complementary information about the continental glaciers but also about ice-sheet behavior. Marine core V29-191 (McManus et al., 1994) indicates that during the continental stadials Melisey I and II, and at the MIS 5/4 boundary, the North Atlantic experienced iceberg discharges named cold events $\mathrm{C} 24$ and 21 (McManus et al., 1994), relabeled GS24-NAC24 and GS21-NAC21 by (Rousseau et al., 2006b). Such cold events indicate the occurrence of continental ice sheets able to calve icebergs that carried ice-rafted material through the ocean (Kukla et al., 1997). These ice sheets are obviously large enough to contribute to the production of fine material, available in their front moraines. Core V29-191 also yielded evidence that during the cold events NAC24, 21 and 20, surface waters contained high percentages of Neogloboquadrina pachyderma sinistral (Fig. 7). Such an increase in cold-temperature planktonic foraminifera suggests an advance of the polar front in this area (McManus et al., 1994), constraining therefore the path of the depressions over Europe.

While the size of these stadial ice sheets was large enough to generate icebergs, Kutzbach et al. (1993) concluded, though, that they did not produce a substantial climatological deviation of the polar jet stream, as reconstructed at the last glacial maximum (Manabe and Broccoli, 1985; Kutzbach et al., 1993). Therefore, one or more other mechanisms must be considered to induce strong winds over Europe that could help build the observed units of dust and silt at the DV site.

MS units occur in Central European loess sequences in a precise geomorphological context, namely slope deposition. Their westernmost occurrence is in the Rhine River valley in Germany (Seelos and Sirocko, 2007) and in Alsace, where Rousseau and co-workers recognized the original Marker II (Rousseau et al., 1998a, b). In this area, the MS units are well preserved and they follow the stratigraphic succession described by Kukla and Lozek (1961) for Czech and Slovakian deposits. In other sites in Northern France, however, eolian deposits documented in basal pedocomplexes correspond to a loess deposit (Antoine et al., 1999), while in Ukraine, eolian silts at Vyazivok Tyasmyn and Pryluky have also been observed during MIS 5, and interpreted as strictly coeval with marker silts (Rousseau et al., 2001).

In the context of peat deposits, Seret et al. (1990) noticed the occurrence of eolian elements in the Grande Pile stratigraphy. They showed that wind-blown sediments are mostly observed during the Melisey I and II stadials. We propose therewith that marker silts are distributed throughout the western part of the Eurasian continent, from the Rhine valley to the Dnieper plain in western Ukraine. ES layers could have been similarly distributed as well, which seems remarkable as this area shows a particular geomorphological context with the main relief, the Alps, oriented W-E.

Dust storms of continental extent seem, therefore, to be the most appropriate candidate for a satisfactory explanation of the deposition of the marker and eolian silts during MIS 5. This interpretation of the European loess series appears to be at present the most plausible one, with a succession of major dust events during Greenland stadials, especially those that record, across the European corridor at $51^{\circ} \mathrm{N}$, the abrupt climate changes of MIS 3 and 2 (Rousseau et al., 2007c) (Fig. 2).

\subsection{Dust storms and climate}

Numerous reports present major dust events worldwide. However, these events are rather rare in Europe, despite the transport of African dust towards Western Europe across the Mediterranean (Dalmeida, 1986). Kukla (1975) reported 
that on 5 April 1960, a storm deposited three centimeters of dust over parts of Romania, and that this dust was carried from the Kalmyk steppe in Central Asia, i.e. a distance of over $2000 \mathrm{~km}$. Recently, several dust storms were reported in China in April 1990 (Zhang et al., 1991), while a particularly strong one occurred in May 1993 (Derbyshire et al., 1998; Wang et al., 2004; Shao and Dong, 2006).

The 2001 dust event in China is considered as the strongest one ever recorded, in its intensity as well as in the extent of its coverage: $2.5 \times 10^{8}$ metric tons of particles were released into the atmosphere. This event lasted for 10 days, from the dust emission into the atmosphere until the first deposition on the other side of the Pacific, on the West Coast of North America (Gong et al., 2003; Simpson et al., 2003). The more recent Australian (Choobari et al., 2012) and United States dust events - in 2009, in 2010 and in 2012, respectively were also large-amplitude phenomena that could serve as plausible analogs for similar events during interglacial dust intervals.

Several climatic elements characterize these modern dust storms. First, the dust emission is linked to total lack of or, at least, depletion of vegetation cover, and to a land surface condition that reduces precipitation, at least on a regional scale. Furthermore, the long-range dust transport implies, following Pye (1987):

a. strong heating of the ground, which leads to the formation of a deep mixed layer;

b. an upper-level momentum source, which is linked to the occurrence of a cold front that produces ascending trajectories and a large-scale convergence;

c. an enhanced horizontal pressure gradient, associated with a particular circulation pattern.

The characteristics of inferred past dust events during the above-mentioned stadials fit this characterization of weather conditions during dust storms relatively well. Substantial uncertainties in the identification of these conditions remain, however, due to: (i) the exact timing of the paleo-dust events; (ii) the origin of the material; (iii) the climatic scenario under which the dust deposits occurred; and (iv) the most likely mechanism responsible for the dust events. We now consider and attempt to remove these uncertainties, one by one.

\subsubsection{Exact timing of our paleo-dust events}

The overall position of the silt events in the stratigraphy of the bottom of the last climate cycle is given in Fig. 6. The error bars related to the dating method prevent, however, the identification of the exact timing of these continental dust events. Still, the new OSL dates support the correlations with the cold events observed in the marine cores and with the vegetation changes in continental records. From these correlations, one can estimate that silt events last for about a maximum of $2 \mathrm{ka}$.

\subsubsection{Origin of the material and duration of the dust events}

Dust peaks preserved in the Greenland GRIP record also correspond to the dust units observed in the continental record (Fig. 7). This agreement suggests that both types of dust records arise due to the same general atmospheric circulation pattern, even without having to assume the same origin for the dust deposited in the two locations. Indeed, the duration of Greenland stadials is of $1885 \pm 835 \mathrm{yr}$, on the average, according to the NGRIP 2004 timescale (Andersen et al., 2004). Therefore, the dust events identified in the DV records last for about $2000 \mathrm{yr}$ maximum.

This duration can be interpreted in two ways. The first interpretation is to assume that each silt unit corresponds to a single event, which lasted for the whole duration of the unit's deposition; such an interpretation is, however, highly unrealistic. The second interpretation is that each silt unit corresponds to a succession of short events. Each such event would have lasted at most several days, as do the presentday dust storms, it would have occurred during a particular season of the year, and it would have been preserved in the stratigraphy under favorable conditions. The dust record obtained by the Eifel Laminated Sediment Archive (ELSA) project in the cores retrieved from Eifel maar lakes supports such an interpretation. These cores cover the last climate cycle and they also record dust events, interpreted as loess, which are matching several cold events observed in the North Atlantic's NAC26 to NAC18 stadials; the last three of these are of minor magnitude compared to the older ones (Seelos and Sirocko, 2007).

\subsubsection{Climatic scenarios for ES and MS units}

We showed so far that the soil complexes of the DV loess sequence recorded the main climate events of MIS 5 and 4 , in agreement with Greenland ice cores and other climate records of the last glacial cycle, as indicated in Figs. 6 and 7. In particular, the well-dated $\delta^{18} \mathrm{O}$ record from speleothems located along the northern rime of the Alps yield interesting results, indicated by the curve labeled NALPS in Fig. 7. First of all, these speleothems record the climate changes described in Greenland ice cores, especially the warm D/O interstadials. Hiatuses and light $\delta^{18} \mathrm{O}$ values correspond to the Greenland stadials, as well as to the cold events (C) described in the North Atlantic by McManus et al. (1994) (Fig. 7).

The oxygen isotope composition of the speleothems is representative of the regional precipitation; in the Northern Alps, the precipitation originates mainly from the North Atlantic and from Central European land areas (Sodemann and Zubler, 2010). A look at the NALPS record during MIS 5 reveals that the ES events, as well as the interstadials, show a moisture transport that must originate from oceanic areas to the west, like in the modern atmospheric flow pattern of dominant westerlies. The hiatuses in the NALPS $\delta^{18} \mathrm{O}$ record, 
however, are correlated with the occurrence of the MS units and indicate a lack of moisture supply from the west, leading us to surmise that another circulation pattern prevailed during these time intervals.

Annual precipitation estimates reconstructed from the Grande Pile pollen record indicate low precipitation - of about $500 \mathrm{~mm}$ vs. the modern $1080 \mathrm{~mm}$ - during the time interval that corresponds to the deposition of the first Marker (Rousseau et al., 2006a). Such a low precipitation amount implies particularly dry conditions, which are highly favorable for dust emission. These particularly well dated records, therefore show that the speleothems continue to grow during some cold intervals, characterizing the availability of enough moisture supply under cold conditions, i.e. precipitation, for the speleothem to grow, while showing a hiatus during other cold intervals. The latter, based on the U/Th dates measured, correspond to North Atlantic cold events NAC19, 20, and 22 and part of NAC24. Figure 7 shows the correlation between the DV sequence units, the Greenland records, and the NALPS speleothem composite record. ES are correlated with NALPS intervals during which deposition the speleothems continue to grow thanks to the moisture supply yielded through the northwesterly winds. On the contrary, MS are correlated with the "no records" in NALPS composite, corresponding highly probably to the lack of moisture supply, due to a strong reduction of the westerly circulation. These variations in moisture supply are also in agreement with the FDS variation measured in the studied sequence.

By extension, we propose here that the marker silts deposited during MIS 5 are due to an atmospheric circulation pattern that differed from the one prevailing during the rest of the record. In other words, these dust events testify to atmospheric conditions that are unlike those recorded during the rest of MIS 5, but also unlike those associated with the loess deposition during the glacial interval of MIS 4, 3 and 2 over Europe (Sima et al., 2009, 2013).

\subsubsection{Blocking structure and polar air outbreaks over Europe}

To seek an explanation of the dust events that gave rise to the marker silts, we need to consider mechanisms of meridional air-mass dynamics and energy exchanges. At present, the mid-latitudes of the Northern Hemisphere (NH) are dominated by westerly zonal flow, which is stronger in winter than in summer (Lorenz, 1967; Peixoto and Oort, 1992). Even now, the dominant westerlies in the NH have a stronger wavy component than in the Southern Hemisphere, due to the former's greater continentality; the $\mathrm{NH}$ continents induce quasi-permanent ridges and troughs into the westerly flow due to both topographic and thermal effects (Charney and Eliassen, 1949; Hoskins and Pearce, 1983). Marengo and Rogers (2001) recently made some of the same points in a paleoclimatic context.
The meridional component of the $\mathrm{NH}$ flow is occasionally strengthened during blocking events (Rossby, 1939; Namias, 1950; Charney and Devore, 1979). The frequency, duration and predictability of blocking events have been an active area of research in dynamic meteorology for the last few decades (Ghil and Childress, 1987; Ghil and Robertson, 2002). The idea that the frequency and duration of these events might change as a cause, manifestation or consequence of climate change goes back at least to Rex (1950) and has been further examined in Chapter 6 of Ghil and Childress (1987) and by Corti et al. (1999), among others. Slonosky et al. (2000) have documented such changes in European climate over the last two centuries.

The presence of a blocking ridge favors polar air outbreaks. These air masses originate in high latitudes; they are organized into mobile high-pressure lenses of nearly circular shape and of relatively large scale, being $2000-3000 \mathrm{~km}$ in diameter, and they migrate into the mid-latitudes by coldair advection. Their migration is rapid and their path is controlled by the continental topography, the thickness of the air mass, and the precise location of the blocking ridge (Fig. 8). These outbreaks occur when the pole-to-equator temperature gradient is high (Namias, 1950), which is the case during the cold seasons, i.e., in NH fall to spring.

D'Andrea et al. (1998) carried out a comparison of climate simulations with 15 general circulation models (GCMs), and noticed the prevalence of blocking events over the EuroAtlantic sector in late winter and spring. These are precisely the seasons that Sima et al. $(2009,2013)$ recognized as the most favorable for dust emission under stadial conditions. Polar air outbreaks are thus a likely mechanism for the dust events we wish to explain herein, since they are associated with rapid low-level airstreams.

An amplification of this mechanism is to be expected during stadial intervals, when Europe experienced colder conditions than at present. During such a colder climate, mid-latitude disturbances were more violent as a result of stronger temperature contrasts between polar and temperate air masses. Climate variations calculated for stadial conditions across the $51^{\circ} \mathrm{N}$ parallel (Sima et al., 2009, 2013) show high gradients in spring, which yield a frontal condition of cold air masses moving over a heated surface. Such conditions, in turn, favor strong vertical motion over open landscapes with reduced vegetation. All these elements enhance dust emission and subsequent dust storms of continental magnitude in late winter and spring, while they are much reduced or totally nonexistent in summer.

In Western and Central Europe, the main relief is basically oriented NE-SW in Scandinavia and West-East for the Alps further south. This distribution of elevated areas (Rex, 1950) was probably enhanced by the occurrence of larger mountain-massif ice caps during the stadials, an enhancement that was likely to strengthen air-mass exchanges with respect to present-day conditions, and thus contribute to the deposition of the marker silts. The polar-air outbreaks were 

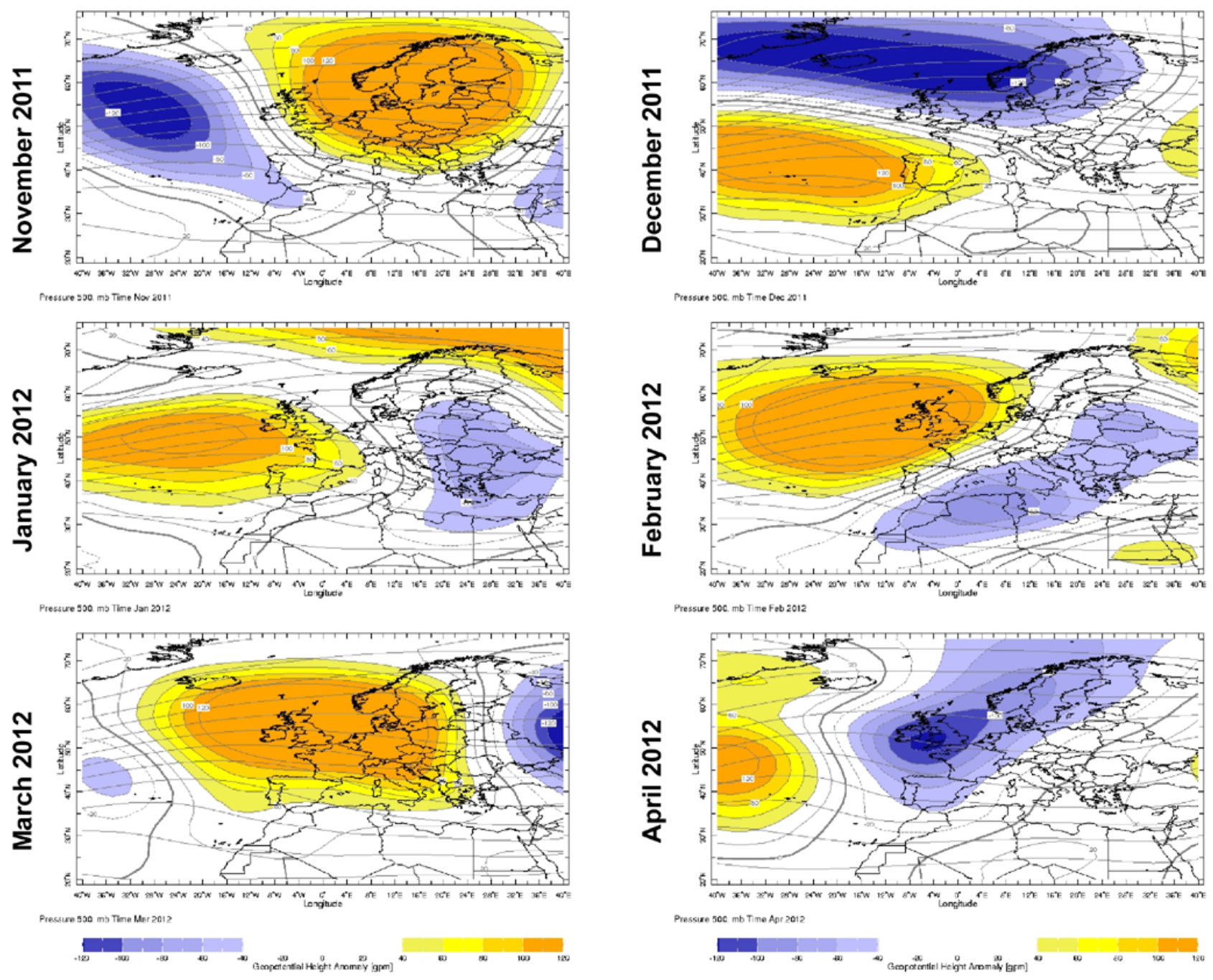

Fig. 8. Maps of geopotential height anomalies at $500 \mathrm{hPa}$ that show the onset, evolution and collapse of the blocking structure that occurred over Eastern North Atlantic and Western Europe in late 2011 and early 2012. Panels are organized from left-to-right and top-to-bottom (November 2011 to April 2012; negative anomalies in cold colors and positive ones in warm colors, while the contour lines indicate isopleths of the full-field climatology. Monthly geopotential height data from the reanalysis of the US National Centers for Environmental Prediction (NCEP); see data library of the International Research Institute for Climate and Society (IRI) at http://iridl.ldeo.columbia.edu/maproom/ .Global/.Atm_Circulation/.Monthly_Std_Height.html. The shading for the anomalies starts at \pm 1 standard deviation, and the color contour interval is 0.5 standard deviation. The contour interval for the climatology is $20 \mathrm{gpm}$.

channeled into a West-East corridor, between Scandinavia and the Alps, that corresponds, in fact, to the western part of the loess belt (Fig. 2).

A similar topographic pattern was responsible for the May 1993 dust storm in China (Derbyshire et al., 1998; Wang et al., 2004; Shao and Dong, 2006), when an intense frontal system over Siberia generated an unusually cold and massive airflow in the Hexi corridor of northern China. Combined with the strong thermal gradient between a warming Tibetan Plateau to the south and the cold Siberian plain (Shao and Dong, 2006), the channeling of this unusual airflow by the topographic effect of the Altai and Tianshan Mountains led to the so-called "dark storm" (Wang et al., 2004; Shao and
Dong, 2006) that affected several provinces, over a total area of the size of France and Spain combined. The paleoclimatic role of this corridor in the accumulation of the loess deposits of Gansu province was discussed by Derbyshire et al. (1998), among others. Similarly, the dust events over China in 2001, Australia in 2009 and the United States in 2011 and 2012 were all related to cold-front dynamics.

On the contrary, east of the Central-European corridor whose southern border are the Alps, beyond the Carpathians, no noticeable topography is present, until the North-Southoriented Urals. Over this East-European Plain, the absence of topographic constraints implies a serious drop in the wind velocity. As a consequence, while markers still occur in the 
western Ukraine (see Fig. 2), they appear to be totally absent further east, until high, West-East-oriented reliefs are present again in Tajikistan.

The climatic scenario described in the preceding paragraphs is a plausible state of affairs for the lower part of the last climatic cycle, before full glacial conditions were reached. The synchronicity of the first main dust events in the Greenland ice cores and in the pedocomplexes of the European loess sequences cannot be purely a matter of chance. On the contrary, the arguments above suggest that these short intervals correspond to specific atmospheric conditions over both high and mid-latitudes in the Euro-Atlantic sector, and generally poor vegetation conditions in European midlatitudes. Given the topographic pattern of western and central Europe, these atmospheric and vegetation conditions provide a plausible explanation of the phenomena that we set out to clarify here.

The occurrence of marker silts in Central Europe while loess was deposited in Western Europe is in agreement with the general scenario proposed by Pye and Zhou (1989) and by Pye (1995). In their scenario of eolian deposits, longrange transport of dust is favored when dust is lifted ahead of cold fronts and incorporated into the upper-level westerlies, while dry fallout from low-level dust clouds forms loess deposits in greater proximity to the dust sources. Marine core V29-191 indicates that the polar front advanced at the time of the sedimentation of the MS units (McManus et al., 1994); Fig. 7). Our hypothesis of the enhancement of blocking activity and polar-air outbreaks during this sedimentation provides the missing origin of regional-scale wind patterns necessary for long-range transport and formation of distal deposits.

\section{Conclusions}

Large-scale continental dust storms are common at present in eastern Asia, Africa and Australia. They represent extreme events (Ghil et al., 2011) that cause major hazards for the population, the livestock and the vegetation of the large regions affected. Reports on the May 1993 dust storm in northwestern China documented huge, wall-like clouds of dust moving rapidly in a direction that lead from a highpressure cell over Siberia to a low-pressure one over southern China. Complete darkness at noon occurred, trees were uprooted or broken, many animals and several people were killed, and a significant layer of dust covered crops. Another dust event, even stronger than the 1993 one, was recorded in April 2001; the latter event led to the export of large amounts of material from the Gobi Desert towards North America and, in some places, combined with locally generated urban pollution there.

Except for rains conveying dust from the Sahara, most of Europe does not experience at present continental dust storms. During the previous interglacial and early glacial period, however, striking eolian-silt deposits have been found in loess sequences: these deposits correspond to fine-grained material that has been interpreted as the fingerprint of largescale dust events.

The penultimate interglacial and early glacial, equivalent to marine stage MIS 5, experienced major dust events that have left their imprint on European terrestrial records. These events are clearly visible in loess sequences by their whitish color ( $L^{*}$ of about $50 \%$ ), overlying and underlying dark chernozem paleosols of MIS-5 age. They are mostly recorded in Central Europe and their western limit appears to be the Rhine River valley.

We described here the base of the Dolni Vestonice (Czech Republic) loess sequence (Figs. 3 and 5 here) as the reference for these stratigraphic horizons. Such units were formed during intervals characterized by sparse vegetation - as identified by high $\delta^{13} \mathrm{C}$ values and low magnetic susceptibility and they show finer grain size values, lower percentages in fine sand and higher ones in clay content than the overlying pleniglacial loess deposits.

G. Kukla and associates described some of these dust horizons as "markers" in the 1960s and early 1970s (Kukla and Lozek, 1961); see Fig. 4 here); they are dated at about 111$109 \mathrm{ka}$ and $93-2 \mathrm{ka}$, a last one being slightly visible at about 75-73 ka. Other dust horizons have been described as eolian silts (ES) and correspond to the loess material of Kukla's cycles. The ES units are observed in the same sequence and are dated at about 106-105 ka, 88-86 ka, and 78.5-77 ka. These dates are determined by considering the OSL ages with their errors measured on the studied sequence and the comparison with Greenland ice-core and European speleothem chronologies.

All these eolian horizons correspond to short events of about $2 \mathrm{ka}$ maximum in duration on the average; they are synchronous with advances of the polar front over the North Atlantic, as recorded in marine cores as cold (C) events (Figs. 5-7 here). They also correlate with abrupt changes observed in European vegetation. The comparison with the $\delta^{18} \mathrm{O}$ record from Northern Alps speleothems shows that, while ES appear to be coeval with moisture supply from the North Atlantic, the marker silts do not show such a relationship. This decoupling between the two modes of dust deposition during MIS 5 differs from the pleniglacial situation, in which loess sedimentation in Europe tracks the Greenland dust record, while it is consistent with westerly transport. We conclude that the occurrence of these dust events in the MIS 5 stratigraphy corresponds to a climatic mechanism that links polar-air outbreaks to blocking action associated with atmospheric circulation patterns that favor meridional flow.

Acknowledgements. We would like to thank Joe Mason and an anonymous reviewer for constructive comments of the discussion manuscript. This study is supported by the French Agence Nationale pour la Recherche (ANR) through the ACTES project ANR-08-BLAN-0227/CSD-6 at LMD in Ecole Normale 
Supérieure, and through grant DE-SC0006694 from the U.S. Department of Energy and grant DMS-0934426 from the U.S. National Science Foundation at UCLA. This is LDEO contribution 2013-7725, LSCE contribution 5055, IPGP contribution 3434.

Edited by: V. Rath

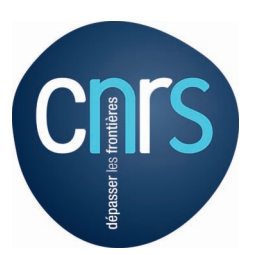

The publication of this article is financed by CNRS-INSU.

\section{References}

An, Z. S., Kukla, G., Porter, S. C., and Xiao, J. L.: Magnetic susceptibility evidence of monsoon variation on the loess plateau of Central China during the last 130,000 years., Quaternary Res., 36, 29-36, 1991.

Andersen, K. K., Azuma, N., Barnola, J. M., Bigler, M., Biscaye, P., Caillon, N., Chappellaz, J., Clausen, H. B., DahlJensen, D., Fischer, H., Fluckiger, J., Fritzsche, D., Fujii, Y., Goto-Azuma, K., Gronvold, K., Gundestrup, N. S., Hansson, M., Huber, C., Hvidberg, C. S., Johnsen, S. J., Jonsell, U., Jouzel, J., Kipfstuhl, S., Landais, A., Leuenberger, M., Lorrain, R., Masson-Delmotte, V., Miller, H., Motoyama, H., Narita, H., Popp, T., Rasmussen, S. O., Raynaud, D., Rothlisberger, R., Ruth, U., Samyn, D., Schwander, J., Shoji, H., Siggard-Andersen, M. L., Steffensen, J. P., Stocker, T., Sveinbjornsdottir, A. E., Svensson, A., Takata, M., Tison, J. L., Thorsteinsson, T., Watanabe, O., Wilhelms, F., White, J. W. C., and Project, N. G. I. C.: High-resolution record of Northern Hemisphere climate extending into the last interglacial period, Nature, 431, 147-151, doi:10.1038/nature02805, 2004.

Antoine, P., Rousseau, D. D., Lautridou, J. P., and Hatté, C.: Last interglacial-glacial climatic cycle in loess-paleosol successions of north-western France, Boreas, 28, 551-563, 1999.

Antoine, P., Rousseau, D. D., Zöller, L., Lang, A., Munaut, A. V., Hatté, C., and Fontugne, M.: High-resolution record of the last interglacial-glacial cycle in the loess palaeosol sequences of Nussloch (Rhine Valley-Germany), Quaternary Int., 76/77, 211-229, 2001.

Antoine, P., Rousseau, D. D., Fuchs, M., Hatte, C., Gauthier, C., Markovic, S. B., Jovanovic, M., Gaudenyi, T., Moine, O., and Rossignol, J.: High-resolution record of the last climatic cycle in the southern Carpathian Basin (Surduk, Vojvodina, Serbia), Quaternary Int., 198, 19-36, doi:10.1016/j.quaint.2008.12.008, 2009a.

Antoine, P., Rousseau, D. D., Moine, O., Kunesch, S., Hatte, C., Lang, A., Tissoux, H., and Zöller, L.: Rapid and cyclic aeolian deposition during the Last Glacial in European loess: a highresolution record from Nussloch, Germany, Quaternary Sci. Rev., 28, 2955-2973, doi:10.1016/j.quascirev.2009.08.001, $2009 \mathrm{~b}$.

Antoine, P., Rousseau, D. D., Degeai, J. P., Moine, O., Lagroix, F., Kreutzer, S., Fuchs, M., Hatté, C., Gauthier, C., Svoboda, J., and Lisa, L.: High-resolution record of the environmental response to climatic variations during the Last Interglacial-Glacial cycle in Central Europe: the loess-palaeosol sequence of Dolní
Věstonice (Czech Republic), Quaternary Sci. Rev., 67, 17-38, doi:10.1016/j.quascirev.2013.01.014, 2013.

Biscaye, P. E., Grousset, F. E., Revel, M., Van der Gaast, S., Zielinski, G. A., Vaars, A., and Kukla, G.: Asian provenance of glacial dust (Stage 2) in the GISP2 ice core, summit, Greenland, J. Geophys. Res., 102, 26765-2726, 1997.

Boch, R., Cheng, H., Spötl, C., Edwards, R. L., Wang, X., and Häuselmann, Ph.: NALPS: a precisely dated European climate record 120-60 ka, Clim. Past, 7, 1247-1259, doi:10.5194/cp-71247-2011, 2011.

Bond, G. and Lotti, R.: Iceberg discharges into the North Atlantic on millennial time scales during the last glaciation, Science, 267, 1005-1010, 1995.

Bond, G., Heinrich, H., Broecker, W., Labeyrie, L., McManus, J., Andrews, J., Huon, S., Jantschik, R., Clasen, S., Simet, C., Tedesco, K., Klas, M., Bonani, G., and Ivy, S.: Evidence for massive discharges of icebergs into the North Atlantic Ocean during the last glacial period, Nature, 360, 245-249, 1992.

Bory, A. J. M., Biscaye, P. E., Svensson, A., and Grousset, F. E.: Seasonal variability in the origin of recent atmospheric mineral dust at NorthGRIP, Greenland, Earth Planet. Sc. Lett., 196, 123134, 2002.

Chappellaz, J., Brook, E., Blunier, T., and Malaizé, B.: $\mathrm{CH}_{4}$ and $\delta^{18} \mathrm{O}$ of $\mathrm{O}_{2}$ records from Antarctic and Greenland ice: A clue for stratigraphic disturbance in the bottom part of the Greenland Ice Core Project and the Greenland Ice Sheet Project 2 ice cores, J. Geophys. Res., 102, 26547-26557, 1997.

Charney, J. G. and Devore, J. G.: Multiple flow equilibria in the atmosphere and blocking, J. Atmos. Sci., 36, 1205-1216, doi:10.1175/1520-0469(1979)036<1205:mfeita>2.0.co;2, 1979.

Charney, J. G. and Eliassen, A.: A numerical method for predicting the perturbations of the middle latitude westerlies, Tellus, 1, 38$54,1949$.

Choobari, O. A., Zawar-Reza, P., and Sturman, A.: Atmospheric forcing of the three-dimensional distribution of dust particles over Australia: A case study, J. Geophys. Res., 117, D11206, doi:10.1029/2012jd017748, 2012.

Corti, S., Molteni, F., and Palmer, T. N.: Signature of recent climate change in frequencies of natural atmospheric circulation regimes, Nature, 398, 799-802, 1999.

D’Andrea, F., Tibaldi, S., Blackburn, M., Boer, G., Deque, M., Dix, M. R., Dugas, B., Ferranti, L., Iwasaki, T., Kitoh, A., Pope, V., Randall, D., Roeckner, E., Straus, D., Stern, W., Van den Dool, H., and Williamson, D.: Northern Hemisphere atmospheric blocking as simulated by 15 atmospheric general circulation models in the period 1979-1988, Clim. Dynam., 14, 385-407, doi:10.1007/s003820050230, 1998.

Dalmeida, G. A.: A model for Saharan dust transport, J. Clim. Appl. Meteorol., 25, 903-916, doi:10.1175/15200450(1986)025<0903:amfsdt>2.0.co;2, 1986.

Dansgaard, W. and Oeschger, H.: Past environmental long-term records from the Arctic, in: The Environmental Record in Glaciers and Ice Sheets, edited by: Oeschger, H. and Langway, C. C., John Wiley \& Sons, Chichester, 287-318, 1989.

Dansgaard, W., Clausen, H. B., Gundestrup, N., Hammer, C. U. J., Johnsen, S. F., Kristinsdottir, P. M., and Reeh, N.: A new Greenland deep ice core, Science, 218, 1273-1277, 1982.

Dansggard, W., Clausen, H. B., Gundestrup, N., Johnsen, S. F., and Rygner, C.: Dating and climatic interpretation of two deep 
Greenland ice cores, in: Greenland Ice Core: Geophysics, Geochemistry, and the Environment, edited by: Langway, C. C., Oeschger, H., and Dansgaard, W., Geophysical Monograph, Washington DC, 71-76, 1985.

Dansgaard, W., Johnsen, S. J., Clausen, H. B., Dahi-Jensen, D., Gundestrup, N. S., Hammer, C. U., Hvidberg, C. S., Steffensen, J. P., Sveinbjörnsdottir, A. E., Jouzel, J., and Bond, G.: Evidence for general instability of past climate from a 250-kyr ice-core record, Nature, 364, 218-220, 1993.

Debret, M., Sebag, D., Desmet, M., Balsam, W., Copard, Y., Mourier, B., Susperrigui, A. S., Arnaud, F., Bentaleb, I., Chapron, E., Lallier-Verges, E., and Winiarski, T.: Spectrocolorimetric interpretation of sedimentary dynamics: The new "Q7/4 diagram", Earth-Rev. Rev., 109, 1-19, doi:10.1016/j.earscirev.2011.07.002, 2011.

Demek, J. and Kukla, J.: Periglazialzone, löss und paläolithikum der Tschechoslowakei, Czechoslovak Academy of Sciences, Institute of Geography, Brno, Brno, 156 pp., 1969.

Derbyshire, E., Meng, X. M., and Kemp, R. A.: Provenance, transport and characteristics of modern aeolian dust in western Gansu Province, China, and interpretation of the Quaternary loess record, J. Arid Environ., 39, 497-516, doi:10.1006/jare.1997.0369, 1998 .

Ding, Z. L., Rutter, N., Han, J. T., and Liu, T. S.: A coupled environmental system formed at about 2.5 Ma in East Asia., Palaeogeogr. Palaeocl., 94, 223-242, 1992.

Ding, Z. L., Ren, J. Z., Yang, S. L., and Liu, T. S.: Climate instability during the penultimate glaciation: Evidence from two highresolution loess records, China, J. Geophys. Res., 104, 20123 20132, doi:10.1029/1999jb900183, 1999.

Ding, Z. L., Ranov, V., Yang, S. L., Finaev, A., Han, J. M., and Wang, G. A.: The loess record in southern Tajikistan and correlation with Chinese loess, Earth Planet. Sc. Lett., 200, 387-400, doi:10.1016/s0012-821x(02)00637-4, 2002.

Fecan, F., Marticorena, B., and Bergametti, G.: Parametrization of the increase of the aeolian erosion threshold wind friction velocity due to soil moisture for arid and semi-arid areas, Ann. Geophys., 17, 149-157, 1999,

http://www.ann-geophys.net/17/149/1999/.

Fischer, H., Siggaard-Andersen, M. L., Ruth, U., Rothlisberger, R., and Wolff, E.: Glacial/interglacial changes in mineral dust and sea-salt records in polar ice cores: Sources, transport, and deposition, Rev. Geophys., 45, RG1002, doi:10.1029/2005RG000192, 2007.

Forster, T. and Heller, F.: Loess deposits from the Tajik depression (Central Asia): Magnetic properties and paleoclimate, Earth Planet. Sc. Lett., 128, 501-512, 1994.

Fuchs, M., Kreutzer, S., Rousseau, D. D., Antoine, P., Hatté, C., Lagroix, F., Moine, O., Gauthier, C., Svoboda, J., and Lisa, L.: The loess sequence of Dolni Vestonice, Czech Republic: A new OSL-based chronology of the Last Climatic Cycle, Boreas, 42, 664-677, doi:10.1111/j.1502-3885.2012.00299.x, 2013.

Ghil, M. and Childress, S.: Topics in Geophysical Fluid Dynamics: Atmospheric Dynamics, Dynamo Theory and Climate Dynamics, Springer-Verlag, New-York, 485 pp., 1987.

Ghil, M. and Robertson, A. W.: "Waves" vs. "particles" in the atmosphere's phase space: A pathway to long-range forecasting?, P. Natl. Acad. Sci. USA, 99, 2493-2500, doi:10.1073/pnas.012580899, 2002.
Ghil, M., Yiou, P., Hallegatte, S., Malamud, B. D., Naveau, P., Soloviev, A., Friederichs, P., Keilis-Borok, V., Kondrashov, D., Kossobokov, V., Mestre, O., Nicolis, C., Rust, H. W., Shebalin, P., Vrac, M., Witt, A., and Zaliapin, I.: Extreme events: dynamics, statistics and prediction, Nonlinear Proc. Geoph., 18, 295350, doi:10.5194/npg-18-295-2011, 2011.

Gillette, D. A. and Chen, W. N.: Size distributions of saltating grains: An important variable in the production of suspended particles, Earth Surf. Proce. Land., 24, 449462, doi:10.1002/(sici)1096-9837(199905)24:5<449::aidesp1>3.0.co;2-e, 1999.

Gillette, D. A. and Goodwin, P. A.: Microscale Transport of SandSized Soil Aggregates Eroded by Wind, J. Geophys. Res., 79, 4080-4084, 1974.

Gomes, L., Rajot, J. L., Alfaro, S. C., and Gaudichet, A.: Validation of a dust production model from measurements performed in semi-arid agricultural areas of Spain and Niger, Catena, 52, 257-271, doi:10.1016/s0341-8162(03)00017-1, 2003.

Gong, S. L., Zhang, X. Y., Zhao, T. L., McKendry, I. G., Jaffe, D. A., and Lu, N. M.: Characterization of soil dust aerosol in China and its transport and distribution during 2001 ACE-Asia: 2. Model simulation and validation, J. Geophys. Res., 108, 4262, doi:10.1029/2002jd002633, 2003.

GRIP members: Climate instability during the last interglacial period recorded in the GRIP ice core, Nature, 364, 203-207, 1993.

$\mathrm{Gu}, \mathrm{Z}$., Liu, R., and Liu, Y.: Response of the stable isotopic composition of loess-paleosol carbonate to paleoenvironmental changes., in: Loess, environment and global change, edited by: Liu, T. S., Science Press, Beijing, 82-92, 1991.

Guo, Z., Liu, T., Guiot, J., Wu, N., Lü, H., Han, J., Liu, J., and Gu, Z.: High frequency pulses of East Asian monsoon climate in the last two glaciations: link with the North Atlantic, Clim. Dynam., 12, 701-709, 1996.

Guo, Z. T., Ruddiman, W. F., Hao, Q. Z., Wu, H. B., Qiao, Y. S., Zhu, R. X., Peng, S. Z., Wei, J. J., Yuan, B. Y., and Liu, T. S.: Onset of Asian desertification by $22 \mathrm{Myr}$ ago inferred from loess deposits in China, Nature, 416, 159-163, 2002.

Hammer, C. U., Clausen, H. B., Dansgaard, D., Neftel, A., Kristinsdottir, P., and Johnson, E.: Continuous impurity analysis along the Dye 3 deep core, in: Greenland ice core: Geophysics, Geochemistry and the Environment, edited by: Langway, C. C., Oeschger, H., and Dansgaard, W., Geophysical Monograph, Washington DC, 90-94, 1985.

Hatté, C., Fontugne, M., Rousseau, D. D., Antoine, P., Zöller, L., Tisnérat-Laborde, N., and Bentaleb, I.: $\delta^{13} \mathrm{C}$ variations of loess organic matter as a record of the vegetation response to climatic changes during the Weichselian, Geology, 26, 583-586, 1998.

Hatté, C., Antoine, P., Fontugne, M., Rousseau, D. D., TisnératLaborde, N., and Zöller, L.: New chronology and organic matter $\delta^{13} \mathrm{C}$ paleoclimatic significance of Nussloch loess sequence (Rhine Valley, Germany), Quaternary. Int., 62, 85-91, 1999.

Hatté, C., Gauthier, C., Rousseau, D.-D., Antoine, P., Fuchs, M., Lagroix, F., Marković, S. B., Moine, O., and Sima, A.: Excursions to $\mathrm{C}_{4}$ vegetation recorded in the Upper Pleistocene loess of Surduk (Northern Serbia): an organic isotope geochemistry study, Clim. Past, 9, 1001-1014, doi:10.5194/cp-9-1001-2013, 2013.

Heinrich, H.: Origin and consequences of cyclic ice rafting in the Northeast Atlantic Ocean during the past 130,000 years, Quaternary Res., 29, 142-152, 1988. 
Heller, F. and Liu, T. S.: Magnetostratigraphical dating of loess deposits in China, Nature, 300, 1169-1172, 1982.

Heller, F., Liu, X., Liu, T., and Xu, T.: Magnetic susceptibility of loess in China, Earth Planet. Sc. Lett., 103, 301-310, 1991.

Hesse, P. P. and McTainsh, G. H.: Australian dust deposits: modern processes and the Quaternary record, Quaternary Sci. Rev., 22, 2007-2035, doi:10.1016/s0277-3791(03)00164-1, 2003.

Hoskins, B. J. and Pearce, R. P.: Large-Scale Dynamic Processes in the Atmosphere, Academic Press, London/New York, 397 pp., 1983.

Hradilova, J.: New micromorphological knowledge of the last Pleistocene glacial cycle in the loess profile at Praha-Sedlec, J. Czech Geol. Soc., 39, 319-329, 1994.

Hradilova, J. and Stastny, M.: Changes in the clay fraction mineral composition in a loess profile of the last interglacial and early glacial in Praha-Sedlec, Acta Univ. Carol. Geol., 38, 229-238, 1994.

Johnsen, S. J., Dahl-Jensen, D., Gundestrup, N., Steffensen, J. P., Clausen, H. B., Miller, H., Masson-Delmotte, V., Sveinbjörnsdottir, A. E., and White, J.: Oxygen isotope and palaeotemperature records from six Greenland ice-core stations: Camp Century, Dye-3, GRIP, GISP2, Renland and NorthGRIP, J. Quaternary Sci., 16, 299-307, 2001.

Kukla, G. J.: Lithologische Leithorizonte der tschechoslowakischen Lössprofile, Véstnik, 36, 369-372, 1961.

Kukla, G.: Loess stratigraphy of central Europe, in: After the Australopithecines, edited by: Butzer, K. W. and Isaac, G. L., Mouton, The Hague, 99-188, 1975.

Kukla, G.: Pleistocene land-sea correlations. 1. Europe, Earth-Sci. Rev., 13, 307-374, 1977.

Kukla, G.: Loess stratigraphy in Central China, Quaternary Sci. Rev., 6, 191-219, 1987.

Kukla, G. and Lozek, V.: Loess and related deposits, in: Survey of Czechoslovak Quaternary. Czwartozed Europy Srodkowej i Wschodniej. INQUA 6th Int. Congr., Inst. Geol. Prace, Warszawa, 34, 11-28, 1961.

Kukla, G. and Koci, A.: End of the last interglacial in the loess record, Quaternary Res., 2, 374-383, 1972.

Kukla, G., Heller, F., Liu, X. M., Xu, T. C., Liu, T. S., and An, Z. S.: Pleistocene climates in China dated by magnetic susceptibility, Geology, 16, 811-814, 1988.

Kukla, G., McManus, J. F., Rousseau, D. D., and Chuine, I.: How long and how stable was the last interglacial?, Quaternary Sci. Rev., 16, 605-612, 1997.

Kutzbach, J. E., Guetter, P. J., Behling, P. J., and Selin, R.: Simulated Climatic Changes: Results of the COHMAP ClimateModel Experiments, in: Global Climates since the Last Glacial Maximum, edited by: Wright Jr., H. E., Kutzbach, J. E., Webb III, T., Ruddiman, W. F., Street-Perrott, F. A., and Bartlein, P. J., University of Minnesota Press, Minnneapolis, 24-93, 1993.

Lang, A., Hatté, C., Rousseau, D. D., Antoine, P., Fontugne, M., Zöller, L., and Hambach, U.: High-resolution chronologies for loess: comparing $\mathrm{AMS}^{14} \mathrm{C}$ and optical dating results, Quaternary Sci. Rev., 22, 953-959, 2003.

Liu, T. S. (Ed.): Loess and the Environment, edited by: Liu, T. S., China Ocean Press, Beijing, 251 pp., 1985.

Lorenz, E. W.: The Nature and Theory of the General Circulation of the Atmosphere, Word Meteorological Organization, Geneva, Switzerland, 161 pp., 1967.
Lu, H., Wu, N., Nie, G., and Wang, Y.: Phytolith in loess and its bearing on paleovegetation, The series of the XIII InQUA congress, 112-123, 1991.

Manabe, S. and Broccoli, A. J.: The influence of continental ice sheets on the climate of an ice-age, J. Geophys. Res., 90, 21672190, doi:10.1029/JD090iD01p02167, 1985.

Marengo, J. A. and Rogers, J. C.: Polar air outbreaks in the Americas: Assessments and impacts during modern and past climates, in: Interhemispheric climate linkages, edited by: Markgraf, V., Academic Press, San Diego, 31-51, 2001.

Martinson, D. G., Pisias, N. G., Hays, J. D., Imbrie, J., Moore, T. C., and Shackleton, N. J.: Age dating and the orbital theory of the Ice ages: development of a high-resolution 0 to 300,000-year chronostratigraphy, Quaternary Res., 27, 1-29, 1987.

McManus, J. F., Bond, G. C., Broecker, W. S., Johnsen, S., Labeyrie, L., and Higgins, S.: High-resolution climate records from the North Atlantic during the last interglacial, Nature, 371, 326-329, 1994.

Muhs, D. R. and Bettis III, E. A.: Geochemical variations in Peoria loess of western Iowa indicate paleowinds of midcontinental North America during last glaciation, Quaternary Res., 53, 4961, 2000.

Namias, J.: The index cycle and its role in the general circulation, J. Meteorol., 7, 130-139, doi:10.1175/15200469(1950)007<0130:ticair>2.0.co;2, 1950.

Nickling, W. G.: Measurement and modelling of wind erosion from agricultural and natural landscapes: Current status and future outlook, Dust aerosols, loess soils and global change, Seattle, USA, 35-38, 1998.

Pécsi, M.: Loess is not just the accumulation of dust, Quaternary Int., 7/8, 1-21, 1990.

Peixoto, J. P. and Oort, A. H.: Physics of Climate, Physics, A. I. O., Springer Verlag, New-York/London, 520 pp., 1992.

Petit, J. R., Mounier, L., Jouzel, J., Korotkevivch, Y. S., Kotlyakov, V. I., and Lorius, C.: Palaeoclimatological and chronological implications of the Vostok core dust record, Nature, 343, 56-58, 1990.

Porter, S. C. and An, Z. S.: Correlation between climate events in the North Atlantic and China during the last glaciation, Nature, 375, 305-308, 1995.

Pye, K.: Aeolian Dust and Dust Deposits, Academic Press, 1987.

Pye, K.: The nature, origin and accumulation of loess, Quaternary Sci. Rev., 14, 653-657, 1995.

Pye, K. and Zhou, L. P.: Late Pleistocene and Holocene aeolian dust deposition in North China and the Northwest Pacific Ocean, Palaeogeogr. Palaeocl., 73, 11-23, 1989.

Rex, D. F.: Blocking action in the middle troposphere and its effect upon regional climate. Part II: The climatology of blocking action, Tellus, 2, 275-301, 1950.

Rossby, C. G.: Relation between variations in the intensity of the zonal circulation of the atmosphere and the displacements of the semipermanent centers of action, J. Mar. Res., 2, 38-55, 1939.

Rousseau, D. D.: Climatic transfer function from Quaternary molluscs in European loess deposits, Quaternary Res., 36, 195-209, 1991.

Rousseau, D. D. and Kukla, G.: Late Pleistocene climate record in the Eustis loess section, Nebraska, based on land snail assemblages and magnetic-susceptibility, Quaternary Res., 42, 176187, 1994. 
Rousseau, D. D. and Puisségur, J. J.: A 350,000 years climatic record from the loess sequence of Achenheim, Alsace, France, Boreas, 19, 203-216, 1990.

Rousseau, D. D. and Wu, N. Q.: A new molluscan record of the monsoon variability over the past $130000 \mathrm{yr}$ in the Luochuan loess sequence, China, Geology, 25, 275-278, 1997.

Rousseau, D. D., Puissegur, J. J., and Lautridou, J. P.: Biogeography of the Pleistocene Pleniglacial Malacofaunas in Europe Stratigraphic and Climatic Implications, Palaeogeogr. Palaeocl., 80, 7-23, 1990.

Rousseau, D. D., Kukla, G., Zoller, L., and Hradilova, J.: Early Weichselian dust storm layer at Achenheim in Alsace, France, Boreas, 27, 200-207, 1998a.

Rousseau, D. D., Zoller, L., and Valet, J. P.: Late Pleistocene climatic variations at Achenheim, France, based on a magnetic susceptibility and TL chronology of loess, Quaternary Res., 49, 255-263, 1998b.

Rousseau, D. D., Gerasimenko, N., Matviischina, Z., and Kukla, G.: Late Pleistocene environments of the Central Ukraine, Quaternary Res., 56, 349-356, 2001.

Rousseau, D. D., Antoine, P., Hatté, C., Lang, A., Zöller, L., Fontugne, M., Ben Othman, D., Luck, J. M., Moine, O., Labonne, M., Bentaleb, I., and Jolly, D.: Abrupt millennial climatic changes from Nussloch (Germany) Upper Weichselian eolian records during the Last Glaciation, Quaternary Sci. Rev., 21, 1577-1582, 2002.

Rousseau, D. D., Hatté, C., Guiot, J., Duzer, D., Schevin, P., and Kukla, G.: Reconstruction of the Grande Pile Eemian using inverse modeling of biomes and delta C-13, Quaternary Sci. Rev., 25, 2806-2819, 2006a.

Rousseau, D. D., Kukla, G., and McManus, J.: What is what in the ice and the ocean?, Quaternary Sci. Rev., 25, 2025-2030, 2006 b.

Rousseau, D. D., Antoine, P., Kunesch, S., Hatté, C., Rossignol, J., Packman, S., Lang, A., and Gauthier, C.: Evidence of cyclic dust deposition in the US Great plains during the last deglaciation from the high-resolution analysis of the Peoria Loess in the Eustis sequence (Nebraska, USA), Earth Planet. Sc. Lett., 262, 159-174, doi:10.1016/j.eps1.2007.07.016, 2007a.

Rousseau, D. D., Derbyshire, E., Antoine, P., and Hatté, C.: European loess records, in: Encyclopedia of Quaternary Science, edited by: Elias, S., 4, Elsevier, Amsterdam, 1440-1456, $2007 \mathrm{~b}$.

Rousseau, D. D., Sima, A., Antoine, P., Hatté, C., Lang, A., and Zöller, L.: Link between European and North Atlantic abrupt climate changes over the last glaciation, Geophys. Res. Lett., 34, L22713 doi:10.1029/2007gl031716, 2007c.

Rousseau, D.-D., Antoine, P., Gerasimenko, N., Sima, A., Fuchs, M., Hatté, C., Moine, O., and Zoeller, L.: North Atlantic abrupt climatic events of the last glacial period recorded in Ukrainian loess deposits, Clim. Past, 7, 221-234, doi:10.5194/cp-7-2212011, 2011.

Ruth, U., Wagenbach, D., Steffensen, J. P., and Bigler, M.: Continuous record of microparticle concentration and size distribution in the central Greenland NGRIP ice core during the last glacial period, J. Geophys. Res., 108, 4098, doi:10.1029/2002JD002376, 2003.

Seelos, K. and Sirocko, F.: Abrupt cooling events at the very end of the Last Interglacial, in: The Climate of Past Interglacials, edited by: Sirocko, F., Claussen, M., Sanchez Goni, M. F., and Litt,
T., Developments in Quaternary Science, Elsevier, Amsterdam, 207-229, 2007.

Seret, G., Dricot, E., and Wansard, G.: Evidence for an early glacial maximum in the French Vosges during the last glacial cycle, Nature, 346, 453-456, 1990.

Shackleton, N. J., An, Z., Dodonov, A. E., Gavin, J., Kukla, G. J., Ranov, V. A., and Zhou, L. P.: Accumulation rate of Loess in Tadjikistan and China: Relationship with global ice volume cycles, Quat. Proc., 4, 1-6, 1995.

Shao, Y.: A model for mineral dust emission, J. Geophys. Res., 106, 20239-20254, 2001.

Shao, Y. and Dong, C. H.: A review on East Asian dust storm climate, modelling and monitoring, Global Planet. Change, 52, 122, 2006.

Sima, A., Rousseau, D. D., Kageyama, M., Ramstein, G., Schulz, M., Balkanski, Y., Antoine, P., Dulac, F., and Hatté, C.: Imprint of North-Atlantic abrupt climate changes on western European loess deposits as viewed in a dust emission model, Quaternary Sci. Rev., 28, 2851-2866, doi:10.1016/j.quascirev.2009.07.016, 2009.

Sima, A., Kageyama, M., Rousseau, D.-D., Ramstein, G., Balkanski, Y., Antoine, P., and Hatté, C.: Modeling dust emission response to North Atlantic millennial-scale climate variations from the perspective of East European MIS 3 loess deposits, Clim. Past, 9, 1385-1402, doi:10.5194/cp-9-1385-2013, 2013.

Simpson, J. J., Hufford, G. L., Servranckx, R., Berg, J., and Pieri, D.: Airborne Asian dust: case study of long-range transport and implications for the detection of volcanic ash, Weather Forecast., 18, 121-141, 2003.

Slonosky, V. C., Jones, P. D., and Davies, T. D.: Variability of the surface atmospheric circulation over Europe, 17741995, Int. J. Climatol., 20, 1875-1897, doi:10.1002/10970088(200012)20:15<1875::AID-JOC593>3.0.CO;2-D, 2000.

Smiley, T. L., Bryson, R. A., King, J. E., Kukla, G. J., and Smith, G. I.: Quaternary paleoclimates, in: Quaternary Nonglacial Geology: Conterminous U.S. The Geology of North America, edited by: Morrison, R. B., The Geological Society of America, Boulder, 13-44, 1991.

Sodemann, H. and Zubler, E.: Seasonal and inter-annual variability of the moisture sources for Alpine precipitation during 19952002, Int. J. Climatol., 30, 947-961, doi:10.1002/joc.1932, 2010

Stuut, J. B., Zabel, M., Ratmeyer, V., Helmke, P., Schefuss, E., Lavik, G., and Schneider, R.: Provenance of present-day eolian dust collected off NW Africa, J. Geophys. Res., 110, D04202, doi:04210.01029/02004JD005161, 2005.

Sun, Y., Clemens, S. C., Morrill, C., Lin, X., Wang, X., and An, Z.: Influence of Atlantic meridional overturning circulation on the East Asian winter monsoon, Nat. Geosci., 5, 46-49, 2012.

Svensson, A., Biscaye, P. E., and Grousset, F. E.: Characterization of late glacial continental dust in the Greenland Ice Core Project ice core, J. Geophys. Res., 105, 4637-4656, doi:10.1029/1999jd901093, 2000.

Tada, R., Irino, T., and Koizumi, I.: Land-ocean linkages over orbital and millennial timescales recorded in late Quaternary sediments of the Japan Sea, Paleoceanography, 14, 236-247, 1999.

Vandenberghe, J.: Grain size of fine-grained windblown sediment: A powerful proxy for process identification, Earth-Sci. Rev., 121, 18-30, 2013. 
Wang, H., Folmer, L. R., and Liu, J. C. L.: Isotope evidence of paleo-El Nino-Southern Oscillation cycles in loess-paleosol record in the central United States, Geology, 28, 771-774, 2000.

Wang, X., Gong, Z., Zhang, J., and Liu, L.: Modern dust storms in China: An overview, J. Arid Environ., 58, 559-574, 2004.

Wang, Y. J., Cheng, H., Edwards, R. L., An, Z. S., Wu, J. Y., Shen, C. C., and Dorale, J. A.: A high-resolution absolute-dated late Pleistocene monsoon record from Hulu Cave, China, Science, 294, 2345-2348, doi:10.1126/science.1064618, 2001.

Wang, Y., Cheng, H., Edwards, R. L., Kong, X., Shao, X., Chen, S., Wu, J., Jiang, X., Wang, X., and An, Z.: Millenial- and orbitalscale changes in the East Asian monsoon over the past 224,000 years, Science, 451, 1090-1093, 2008.
Woillard, G.: Grande Pile peat bog: A continuous pollen record for the last 140,000 years, Quaternary Res., 9, 1-21, 1978.

Wu, N., Lu, H., Sun, X., Guo, Z., Liu, J., and Han, J.: Climatic factor transfer function from opal phytolith and its application in paleoclimate reconstruction of China loess-paleosol sequence, in: Scientia Geologica Sinica, edited by: Wang, S., Science Press, Beijing, 105-114, 1995.

Zhang, G., Wang, X., and Zhang, X.: The synoptic dynamic condition and the features of chemical elements of dustfall event in April 1990 in Beijing, in: Loess, Environment and Global Change, edited by: Liu, T., Science Press, Beijing, 228-234, 1991. 